\title{
The Hidden Foreign Law Debate in Heller: The Proportionality Approach in American Constitutional Law
}

\author{
MOSHE COHEN-ELIYA* \\ IDDO PORAT**
}

\section{TABLE OF CONTENTS}

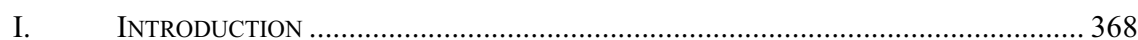

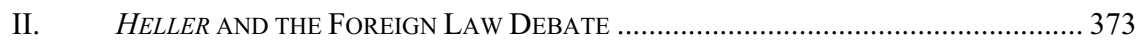

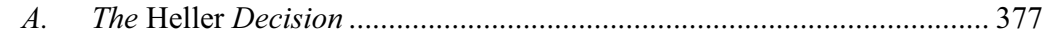

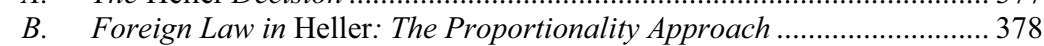

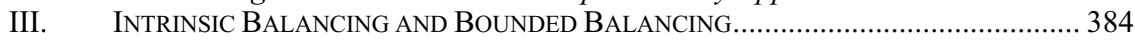

A. Balancing and Proportionality: Doctrinal

Similarities and Beyond.......

B. The Intrinsic Sense of Balancing in Germany..................................... 387

1. The German Organic Conception of the State ................................... 388

* Senior Lecturer, Academic Center of Law and Business, Israel.

** Lecturer, Academic Center of Law and Business, Israel. Visiting Professor of Law, University of San Diego School of Law (2008-2009).

For their helpful comments, we thank Aharon Barak, Alon Harel, Bert Lazerow, Pierre Legrand, and Mike Ramsey. We also wish to thank the participants of the international workshop on Rights, Balancing, and Proportionality in Tel Aviv, January 2009, and especially Robert Alexy, Stephen Gardbaum, Mattias Kumm, Georg Nolte, and Alec Stone Sweet, and the participants of the Faculty Seminar at the University of San Diego School of Law School. Some of the ideas in Part II of this Article were presented in the Harvard-Stanford International Junior Faculty Forum at Stanford University, October 2008. Special thanks go to William Alford, Tino Celluar, Lawrence Friedman, and Sergio López Ayllón for their helpful comments at the Forum. The Max Planck Institute for Comparative Public Law and International Law and the Canadian Government Faculty Research Program provided generous financial support for earlier stages of this research. 
2. Proportionality as an Intrinsic Element of the Organic

Conception of the State ..................................................................... 392

C. The Bounded Sense of Balancing in America ........................................... 395

1. The Suspicion-Based Conception of the State in America ................. 396

2. The Suspicion-Based Conception of the State and

Bounded Balancing.

3. Bounded Balancing...................................................................... 399

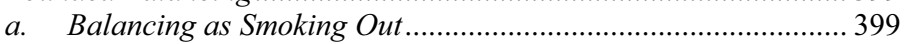

b. Balancing as the Exception Rather than the Rule .................... 402

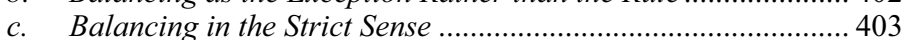

D. The Structural Constitutional Differences Between Germany

and America

IV. AFTERWORD: THE RAMIFICATIONS OF HELLER FOR

THE FoREIGN LAW DEBATE

\section{INTRODUCTION}

District of Columbia v. Heller ${ }^{1}$ is arguably the most important decision of the 2007-2008 Supreme Court term. Pertaining to gun control, the case was met with a deluge of articles ranging from issues of judicial minimalism, to constitutional originalism, to the rules versus standards debate. ${ }^{2}$ One important point was overlooked by commentators, however: the fact that Justice Breyer, in his dissenting opinion, came close to introducing the significant European doctrine of proportionality into American constitutional jurisprudence. Indeed, arguing against the use of a categorical strict scrutiny test in the application of the Second Amendment, Breyer stated:

[A]ny attempt in theory to apply strict scrutiny to gun regulations will in practice turn into an interest-balancing inquiry, with the interests protected by the Second Amendment on one side and the governmental public-safety concerns on the other....

1. 128 S. Ct. 2783 (2008).

2. See, e.g., Akhil Reed Amar, Heller, HLR, and Holistic Legal Reasoning, 122 Harv. L. Rev. 145 (2008); Glenn H. Reynolds \& Brannon P. Denning, Heller's Future in the Lower Courts, 102 Nw. U. L. REV. 2035 (2008); Richard Schragger, The Last Progressive: Justice Breyer, Heller, and "Judicial Judgment," 59 SYRACUSE L. REV. 283 (2008); Reva B. Siegel, Dead or Alive: Originalism as Popular Constitutionalism in Heller, 122 Harv. L. Rev. 191 (2008); Cass R. Sunstein, Second Amendment Minimalism: Heller as Griswold, 122 HARV. L. REV. 246 (2008); J. Harvie Wilkinson III, Of Guns, Abortions, and the Unraveling Rule of Law, 95 VA. L. REV. (forthcoming 2009), available at http://papers.ssrn.com/sol3/papers.cfm?abstract id=1265118; Mark Tushnet, Two Essays on District of Columbia v. Heller (Harvard Pub. Law Working Paper, Paper No. 08-17, 2008), available at http://papers.ssrn.com/sol3/papers. cfm?abstract_id=1189494; Glenn Harlan Reynolds \& Brannon P. Denning, The Year of the Gun: Second Amendment Rights and the Supreme Court, 86 TEX. L. REV. SEE Also 22 (2008), http://www.texaslrev.com/seealso/pdfs/yeargun.pdf. 
. . . Contrary to the majority's unsupported suggestion that this sort of "proportionality" approach is unprecedented, the Court has applied it in various constitutional contexts, including election-law cases, speech cases, and due process cases. ${ }^{3}$

The tremendous influence and importance of the doctrine of proportionality in European constitutional law, as well as many other constitutional systems, cannot be overstated. Proportionality, which essentially requires that rights infringement be proportional to governmental ends, is arguably the most dominant doctrine in constitutional adjudication worldwide. ${ }^{4}$ Since the 1970s, it has expanded to almost every democracy across the globe. ${ }^{5}$ Currently, proportionality is one of the defining features of what can be termed global constitutionalism.

The use of the term "proportionality" by a Justice as well-versed in European constitutional law as Breyer cannot be seen as pure coincidence. ${ }^{6}$

3. Heller, 128 S. Ct. at 2852 (Breyer, J., dissenting) (citations omitted).

4. See, e.g., David M. BeatTy, The Ultimate Rule of Law 159, 171-76 (2004); Aharon Barak, Proportional Effect: The Israeli Experience, 57 U. TORONTO L.J. 369, 370-73 (2007); Dieter Grimm, Proportionality in Canadian and German Constitutional Jurisprudence, 57 U. TORONTO L.J. 383, 384-85 (2007); Vicki C. Jackson, Being Proportional About Proportionality, 21 CONST. CoMmENT. 803 (2004) (presenting a critique of Beatty's approach); Francis G. Jacobs, Recent Developments in the Principle of Proportionality in European Community Law, in THE PrINCIPLE OF PROPORTIONALITY IN THE LAWS OF EUROPE 1, 1 (Evelyn Ellis ed., 1999); Jeffery Jowell \& Anthony Lester, Proportionality: Neither Novel nor Dangerous, in NEW DiRECTIONS IN JUDICIAL REVIEW 51, 53-55 (J.L. Jowell \& D. Oliver eds., 1988); Mattias Kumm, Political Liberalism and the Structure of Rights: On the Place and Limits of the Proportionality Requirement, in Law, Rights AND Discourse: The Legal Philosophy of RoBert AleXY 131, 139-41 (G. Pavlakos ed., 2007); David S. Law, Generic Constitutional Law, 89 MinN. L. Rev. 652, 693-95 (2005); Alec Stone Sweet \& Jud Mathews, Proportionality Balancing and Global Constitutionalism, 47 COLUM. J. TRANSNAT'L L. 72, 73-74 (2008).

5. For a detailed description of the rapid spread of proportionality analysis around the globe, see Stone Sweet \& Mathews, supra note 4, at 74-75, 111-59.

6. Justice Breyer specifically referred to the proportionality approach in his book, Active Liberty. STEPHEN BREYER, ACTIVE LIBERTY: INTERPRETING OUR DEMOCRATIC CONSTITUTION 48-49 (2005). Justice Breyer also participated in a 2001 Yale Law School seminar titled, "Global Constitutionalism: Privacy, Proportionality, The Political Case" (copies of the materials that were distributed among the participants are compiled with the authors). In addition, Justice Breyer has participated in several Salzburg global law seminars. Salzburg Global Seminar, The Honorable Justice Breyer, http://www. salzburgseminar.org/2009/includes/FacultyPopUp.cfm?IDSPECIAL_EVENT=264\&ID Records=637 (last visited May 31, 2009). The Salzburg Global Seminar is an American nongovernmental organization that conducts seminars on law, economics, and politics, and it has proven to be an important forum for dialogue and exchange of ideas amongst leading American and non-American legal scholars and jurists. Accordingly, there appears to be a general view of judicial globalization. See ANNE-MARIE SLAUGHTER, A New World ORDER 70 (2004); Jenny S. Martinez, Towards an International Judicial 
Justice Breyer has used the word proportionality before, but always in the same sense that it bears in common spoken language-proportionate versus disproportionate, or the proportionality of a restriction. ${ }^{7}$ Heller appears to be the first case in which Breyer explicitly used proportionality as a term of art, by using the phrase "proportionality approach." 8 Arguably, at least two messages are implicit in Breyer's deliberate use of this term: (1) that the doctrine of proportionality is analogous to the American concept of balancing interests; and (2) that proportionality is part of American constitutional law. Given the centrality of proportionality analysis in so many other legal systems, the ramifications of these messages are great. The inherent implication is that American constitutional law is not as different from European constitutional law as some commentators and Justices would suggest. ${ }^{9}$ Breyer's dissent in Heller thus marks an important stage in the Court's ongoing debate over the relationship of U.S. constitutional law with foreign constitutional law.

This last step in the foreign law debate is interesting and important in at least two respects. First, the allusion to foreign constitutional law in Heller is implicit rather than explicit. Despite his reference to proportionality, not a sole foreign legal authority was cited by Justice Breyer. Rather, he based his entire argument for proportionality on decisions from American case law that, in his view, manifest the doctrine. ${ }^{10}$ This could represent a shift in strategy regarding the use of foreign law. Instead of

System, 56 STAN. L. REV. 429, 436-37 (2003) (arguing that the extensive reference to foreign law is tied to a common judicial culture that cuts across borders and jurisdictions); Anne-Marie Slaughter, Judicial Globalization, 40 VA. J. INT'L L. 1103, 1104, 1116, 1120 (2000).

7. See, e.g., Thompson v. W. States Med. Ctr., 535 U.S. 357, 388 (2002) (Breyer, J., dissenting) ("[The Court] has examined the restrictions' proportionality, the relation between restriction and objective, the fit between ends and means."); Bartnicki v. Vopper, 532 U.S. 514, 540 (2001) ("[T]he statutes' enforcement would disproportionately harm media freedom.”); Nixon v. Shrink Mo. Gov't PAC, 528 U.S. 377, 402 (2000) ("Rather, [the Court] has balanced interests. And in practice that has meant asking whether the statute burdens any one such interest in a manner out of proportion to the statute's salutary effects upon the others."); United States v. Playboy Entm't Group, Inc., 529 U.S. 803, 846 (2000) (Breyer, J., dissenting) ("Consequently $\S 505$ 's restriction, viewed in light of the proposed alternative, is proportionate to need. That is to say, it restricts speech no more than necessary to further that compelling need.").

8. Heller, $128 \mathrm{~S}$. Ct. at 2852 (Breyer, J., dissenting) (internal quotation marks omitted).

9. See infra note 21.

10. Heller, $128 \mathrm{~S}$. Ct. at 2852 (Breyer, J., dissenting). Breyer cites the following decisions, the first of which was written by him: Thompson, 535 U.S. at 388 (Breyer, J., dissenting) (commercial speech); Nixon, 528 U.S. at 403 (Breyer, J., concurring); Burdick v. Takushi, 504 U.S. 428, 433 (1992) (election regulation); Mathews v. Eldridge, 424 U.S. 319, 339-49 (1976) (due process); Pickering v. Bd. of Educ., 391 U.S. 563, 568 (1968) (government employee speech). Only Breyer's own opinions use the term "proportional." The earlier cases he cites all use the term "balancing" rather than "proportionality." 
introducing foreign law doctrines directly, an attempt is made to find them within American constitutional law. This tactic gives foreign law doctrines American credentials and prevents any criticism over the infiltration of foreign materials into American law. ${ }^{11}$ The second respect in which the Heller dissent is important relates to the use of foreign methodology, as opposed to foreign substantive ideas. Proportionality, after all, is a methodology, or a doctrine; it does not entail a substantive commitment, such as that inherently required by opposition to capital punishment, ${ }^{12}$ or sodomy laws, ${ }^{13}$ or espousing more expansive notions of equality. ${ }^{14}$ The implementation of a foreign methodology marks yet another strategic shift because it can, while appearing neutral, facilitate the subsequent entry of foreign substantive ideas by creating a common framework and language in which constitutional dialogue can occur.

These unique features aside, the validity of this reference to the proportionality approach can still be questioned. In other words, it is unclear whether Justice Breyer was correct in maintaining that a proportionality approach is well established in American constitutional law, or whether Justice Scalia was correct in asserting that Justice Breyer's approach is unprecedented. ${ }^{15}$

This Article first describes the unique attributes of the use of foreign law in the Heller dissent, and then addresses the soundness of the specific claim that the United States and Europe share the common methodology of proportionality. This Article argues that Justice Breyer

11. The strongest criticism against the introduction of foreign law into American constitutional law is voiced by originalists, who argue that such a move is at odds with the understanding of the Constitution as a self-contained document that forms the constituting contract among the individuals who compose the American polity. Thus, any resort to foreign law cannot be viewed as authoritative. Roger P. Alford, Four Mistakes in the Debate on "Outsourcing Authority," 69 ALB. L. REV. 653, 658-60 (2006); Law, supra note 4, at 727-42 (pointing to the democratic deficiency in the Supreme Court's use of foreign law). For a more detailed account of the criticism of reference to foreign law in American constitutional law cases, see infra notes 16-19 and accompanying text.

12. See, e.g., Roper v. Simmons, 543 U.S. 551, 575 (2005) (striking down laws imposing capital punishment for crimes committed by minors); Atkins v. Virginia, 536 U.S. 304, 316 n.21 (2002) (striking down laws imposing capital punishment for crimes committed by the mentally disabled).

13. Lawrence v. Texas, 539 U.S. 558, 577-79 (2003) (striking down the Texas sodomy law that criminalized sodomy between consenting adults).

14. Gutter v. Bollinger, 539 U.S. 306, 344 (2003) (Ginsburg, J., concurring) (citing to an international treaty to support the Court's longstanding determination that raceconscious programs "must have a logical end point").

15. Heller, 128 S. Ct. at 2821. 
was correct in his contention that a doctrinal framework very similar to proportionality is embedded in American constitutional law in the guise of balancing. However, this Article argues that Breyer missed an important divergence between the two doctrines: the significantly different ways in which balancing and proportionality are situated in America and Europe, respectively, owing to their very different historical, cultural, and institutional characteristics. Taking a contextual approach that emphasizes cultural and institutional factors, this Article claims that the two doctrines are, in fact, quite distinct. Thus, insofar as his claims are descriptive, simply indicating similarities between American and European constitutional law, Breyer's claims are only partially valid because they disregard context. However, Breyer might have been engaging in a more normative project: by tossing the term proportionality into the American constitutional lexicon, he might have been seeking to create a framework for bringing the operation and thinking of American constitutional law closer to European constitutional law. This Article therefore explores some indications that the introduction of proportionality into the constitutional law of other countries, such as Canada, may have contributed to their development of a more European frame of mind and has certainly facilitated more extensive dialogue with Europe.

Part I begins with a review of the Heller decision, demonstrating how Justice Breyer's comments were a covert move in the foreign law debate. Part II discusses the validity of Breyer's claim of a similarity in the doctrinal structures of American balancing and European proportionality. Part II illustrates how different conceptions of constitutional culture and of the state's role in the polity produce different approaches towards the concepts of balancing in the United States and proportionality in Europe, thereby distinguishing them significantly despite their doctrinal resemblance. Taking the example of Germany, the birthplace of proportionality and arguably the most influential European country in terms of constitutional law, Part II explains that the country's organic and cooperative conception of the polity has made proportionality and balancing a central and intrinsically important feature of its constitutional framework. This German model of balancing is termed "intrinsic balancing." In the United States, greater public suspicion of the Court and of the government has led to a more minor and subsidiary role for balancing, causing it to have instrumental rather than intrinsic value. This type of balancing is termed "bounded balancing." Part III focuses on structural differences - the way in which rights are defined in constitutional textsto further illustrate the different uses of the concepts of balancing and proportionality in their respective legal systems. Finally, the Afterword closes with some thoughts on constitutional borrowing, using the example of Canada. 


\section{HELLER AND THE FOREIGN LAW DEBATE}

The debate over the appeal to foreign law in American constitutional interpretation has been raging in the Court for some time now. Proponents claim its invaluable contribution in adding the vital perspectives and experience of other countries. ${ }^{16}$ They also hint at the inherent benefits of making U.S. jurisprudence more in tune with the global constitutional community. ${ }^{17}$ Opponents, however, stress the dangers of indeterminacy that arise with the use of foreign law and argue that foreign materials are irrelevant to internal constitutional interpretation. ${ }^{18}$ The latter camp is often associated with a strong democratic conception of the Constitution, viewing it as embodying the particular and distinct commitments of the American people. ${ }^{19}$ Foreign law proponents, in

16. See Anne-Marie Slaughter, A Global Community of Courts, 44 HARV. InT'L L.J. 191 (2003), stating that:

[L]ooking abroad simply helps [Supreme Court Justices] do a better job at home, in the sense that they can approach a particular problem more creatively or with greater insight. Foreign authority is persuasive because it teaches them something they did not know or helps them see an issue in a different and more tractable light.

Id. at 201 .

17. Vicki C. Jackson, Constitutional Comparisons: Convergence, Resistance, Engagement, 119 HARV. L. REV. 109, 111 (2005) ("[C]onsidering foreign and international law within a framework of learning by engagement-assuming neither convergence nor disagreement - is a legitimate interpretive tool that offers modest benefits (and fewer risks than current debate suggests) to the processes of constitutional adjudication."); see also Sujit Choudhry, Globalization in Search of Justification: Toward a Theory of Comparative Constitutional Interpretation, 74 IND. L.J. 819, 835 (1999) (advocating engagement in comparativism through "dialogical" interpretation).

18. Charles Fried, Scholars and Judges: Reason and Power, 23 HARV. J.L. \& PUB. POL'Y 807, 819 (2000) (arguing against Justice Breyer's introduction of foreign law in Printz, saying that "[t]he dispute is particularly striking because it would be one of the few instances of a deliberate attempt by a Justice to expand the canon of authoritative materials from which constitutional common law reasoning might go forward"); Richard Posner, No Thanks, We Already Have Our Own Laws, LEgAL AfF., July-Aug. 2004, at 40, 41 (pointing to the "problem with according even limited precedential weight to foreign or international decisions [which lies in] the promiscuous opportunities that are opened up").

19. Kenneth Anderson, Squaring the Circle? Reconciling Sovereignty and Global Governance Through Global Government Networks, 118 HARV. L. REV. 1255, 1307 (2005) (reviewing SLAUGHTER, supra note 6, and arguing that "[c]onstitutions are unique insofar as they are the constitutive document of a political community. As such, the issue is not so much the content of doctrine but instead its governance - the fact that it comes out of the constitutional and constitutive processes of a particular community"); Jed Rubenfeld, Commentary, Unilateralism and Constitutionalism, 79 N.Y.U. L. REV. 1971,1999 (2004) ("[I]t is critical for constitutional law to be made and interpreted not by international experts, but by national political actors and judges."); Robert H. Bork, 
contrast, tend to espouse a more universalistic approach, one that conceives rights jurisprudence as involving similar problems wherever it develops. ${ }^{20}$

The foreign law debate is interrelated with the debate regarding the extent of American constitutional law's divergence from other constitutional legal systems, known as the question of American exceptionalism. ${ }^{21}$ The more exceptional American constitutional law is, the harder it is to compare it to other constitutional legal systems or to borrow from them. American exceptionalism can be divided into substantive exceptionalism and methodological exceptionalism. ${ }^{22}$ In terms of substantive exceptionalism, commentators have addressed the unique priority given to free speech in American constitutional law, as well as the strong separation of state and religion and the particular U.S. commitment to what has been termed "the twin instruments of death": guns and capital punishment. ${ }^{23}$ From the perspective of methodology under the exceptionalist view, American constitutional law tends to be categorical rather than openended and standard-like; the constitutional analysis is conducted in its entirety in a single stage of identifying whether a constitutional right has been infringed or which category applies to the given case. ${ }^{24}$ European constitutional

Travesty Time, Again: In Its Death-Penalty Decision, the Supreme Court Hits a New Low, NAT'L REV., Mar. 28, 2005, at 17, 18 (criticizing the Court's reference to foreign law, which "in tacit coordination with foreign courts, is moving toward a global bill of rights").

20. Jeremy Waldron, Foreign Law and the Modern Ius Gentium, 119 HarV. L. REV. 129, 138-40, 143 (2005) (advocating a cosmopolitical position that supports reliance on foreign law).

21. The term "American exceptionalism" can be traced back to ALEXIS DE ToCQueVILle, DEMOCRACY IN AMERICA 455-56 (J.P. Mayer ed., George Lawrence trans., Doubleday 1969) (1835). The literature on American exceptionalism is vast. See, e.g., Steven G. Calabresi, "A Shining City on a Hill": American Exceptionalism and the Supreme Court's Practice of Relying on Foreign Law, 86 B.U. L. REV. 1335 (2006) Michael Ignatieff, Introduction: American Exceptionalism and Human Rights, in AMERICAN EXCEPTIONALISM AND HUMAN RighTS 1 (Michael Ignatieff ed., 2005); Harold Hongju Koh, On American Exceptionalism, 55 StAn. L. REV. 1479, 1483 (2003); Frederick Schauer, Freedom of Expression Adjudication in Europe and the United States: A Case Study in Comparative Constitutional Architecture, in EUROPEAN AND US CONSTITUTIONALISM 49, 49-51 (Georg Nolte ed., 2005).

22. See sources cited infra note 65 .

23. Stephen Gardbaum, The Myth and the Reality of American Constitutional Exceptionalism, 107 MicH. L. REV. 391, 395-96 (2008). An accessible review of major aspects of American substantive exceptionalism was provided in a series of articles published recently in The New York Times. The New York Times, American Exception, http://topics.nytimes.com/top/news/us/series/american exception/index.html (last visited May 31, 2009). The series, written by Adam Liptak between October 17, 2007, and September 18, 2008, is entitled American Exception and sets out to "examine commonplace aspects of the American justice system that are virtually unique in the world." Id.

24. Schauer, supra note 21, at 68; Frederick Schauer, The Convergence of Rules and Standards, 2003 N.Z. L. REV. 303, 308-09 (2003); Frederick Schauer, The Exceptional First Amendment, in AMERICAN EXCEPTIONALISM AND HuMAN Rights, 
law, in contrast, is depicted as more standard-like and as a two-stage analysis. The first stage is the identification of an infringement, while in the second stage, the government tries to justify the infringement by showing that it was pursuing a legitimate governmental end using proportional governmental means. ${ }^{25}$ Opponents of the exceptionalist view argue that differences between the United States and other legal systems are overestimated and that American exceptionalism is, to a large extent, a myth: Focusing their criticism on the methodological prong of the exceptionalist approach, ${ }^{26}$ opponents stress that U.S. constitutionalism is facing the same generic problems and using roughly the same set of doctrines as the rest of the legal world. ${ }^{27}$

In the Supreme Court, two of the major participants in both of these debates have been Justice Breyer, who argues for the use of foreign law and, implicitly, against the exceptionalist view, and Justice Scalia, who criticizes a resort to foreign law and advocates exceptionalism. ${ }^{28}$ The

supra note 21, at 29, 32 [hereinafter Schauer, The Exceptional First Amendment]. In addition, see also Mattias Kumm \& Víctor Ferreres Comella, What Is So Special About Constitutional Rights in Private Litigation? A Comparative Analysis of the Function of State Action Requirements and Indirect Horizontal Effect, in THE CONSTITUTION IN PRIVATE RELATIONS: EXPANDING CONSTITUTIONALISM 241, 278, 286 (Andras Sajo \& Renata Uitz eds., 2005). Kumm and Comella state:

It would be false to claim that proportionality analysis and balancing have no role to play in American constitutional law. They obviously do. Yet it is also clear that, unlike the courts used as a point of comparison here, the Supreme Court is more hesitant in its embrace of proportionality analysis and frames inquiries in a way that appears more legalistic and categorical.

Id. at 278 (footnote omitted).

25. Lorraine E. Weinrib, The Postwar Paradigm and American Exceptionalism, in The Migration of Constitutional Ideas 84, 92-98 (Sujit Choudhry ed., 2006).

26. Gardbaum, supra note 23, at 425 ("[W]hile I think Fred Schauer is correct that U.S. free speech jurisprudence is more categorical in this sense, reflecting in part as he argues an exceptionally strong substantive commitment to free speech protection, it should not be automatically inferred that this approach applies to other constitutional rights.") (footnote omitted).

27. See, e.g., BEATTY, supra note 4, at 2-5; Stephen Gardbaum, Limiting Constitutional Rights, 54 UCLA L. REV. 789, 853 (2007); Gardbaum, supra note 23, at 411-16; Law, supra note 4, at 659-60.

28. Justices O'Connor, Kennedy, and Ginsburg have sided with Breyer in the debate. For O'Connor's position, see Sandra Day O'Connor, Commentary, Broadening Our Horizons: Why American Lawyers Must Learn About Foreign Law, Fed. LAw., Sept. 1998, at 20, 20-21. See also O'Connor's dissenting opinion in Roper v. Simmons, stating that "this Nation's evolving understanding of human dignity certainly is neither wholly isolated from, nor inherently at odds with, the values prevailing in other countries." 543 U.S. 551, 605 (2005) (O'Connor, J., dissenting). Additionally, see Justice Ruth Bader Ginsburg, "A Decent Respect to the Opinions of [Human]kind": The 
foreign law debate seems to have begun in the Printz decision in 1997: Justice Breyer's reference to comparative constitutional law to determine whether a federal statute violated American federalism aroused fierce criticism from Justice Scalia. ${ }^{29}$ Between 2002 and 2005, the foreign law debate intensified as the Court addressed such major issues as capital punishment for the mentally disabled, ${ }^{30}$ the constitutionality of sodomy laws, ${ }^{31}$ affirmative action in college admission, ${ }^{32}$ and the applicability of the death penalty to juvenile offenders. ${ }^{33}$

Somewhat surprisingly, there has been no major decision referring to foreign law since Roper was decided in 2005 . The Heller case presented what seemed like the ideal context in which the debate would reappear: like Lawrence and Roper before it, Heller also involved an issue for which the American constitutional approach diverged dramatically from that taken by other systems. The precedence given to the right to bear

Value of a Comparative Perspective in Constitutional Adjudication, 99 AM. SOC'Y INT'L L. Proc. 351, 355 (2005) ("The notion that it is improper to look beyond the borders of the United States in grappling with hard questions has a certain kinship to the view that the U.S. Constitution is a document essentially frozen in time as of the date of its ratification."). In addition, see the characterization of Justice Kennedy's opinion in Roper. Jackson, supra note 17, at 115 (referring to Roper, 543 U.S. at 575, and stating that for Justice Kennedy, "foreign law, practice, and reasoning - though not 'controlling'-helped to confirm the Court's judgment based on the weight of state practices and its view of the moral capacities of adolescents"). Justice Breyer endorsed references to foreign law in The Relevance of Foreign Legal Materials in U.S. Constitutional Cases: A Conversation Between Justice Antonin Scalia and Justice Stephen Breyer, 3 InT'L J. Const. L. 519, 523-24, 537 (2005). Moreover, see Chief Justice Rehnquist's position in William H. Rehnquist, Foreword to DEFINING THE FIELD of Comparative Constitutional Law, at vii, viii (Vicki C. Jackson \& Mark Tushnet eds., 2002), stating that "it's time the U.S. courts began looking to the decisions of other constitutional courts to aid in their own deliberative process." Id. at viii. Justice Scalia is the most vocal opponent of the introduction of foreign law into American constitutional law. In Roper, he stated that "the basic premise of the Court's argumentthat American law should conform to the laws of the rest of the world-ought to be rejected out of hand." Roper, 543 U.S. at 624 (Scalia, J., dissenting); see also Atkins v. Virginia, 536 U.S. 304, 347-48 (2002) (Scalia, J., dissenting). In addition, Justice Thomas, who joined Scalia's dissenting opinion in Roper, and Chief Justice Roberts, who indicated his opposition to the Court's reference to foreign law in his confirmation hearings, both sided with Justice Scalia on this point. See Roper, 543 U.S. at 607; Transcript: Second Day of Hearings on the Nomination of Judge Roberts, N.Y. TIMES, Sept. 13, 2005, http://www.nytimes.com/2005/09/13/politics/politicsspecial1/13text-roberts html?_r=1\&pagewanted=all (presenting Chief Justice Roberts's testimony at his confirmation hearings, in which he stated that "looking at foreign law for support is like looking out over a crowd and picking out your friends").

29. Printz v. United States, 521 U.S. 898, 921 n.11 (1997) (presenting Justice Scalia's criticism that "comparative analysis [is] inappropriate to the task of interpreting a constitution").

30. Atkins, 536 U.S. at 320-21.

31. Lawrence v. Texas, 539 U.S. 558, 578-79 (2003)

32. Grutter v. Bollinger, 539 U.S. 306, 343-44 (2003).

33. Roper, 543 U.S. at 568 . 
arms in the Constitution and American culture is unique. ${ }^{34}$ The special status given to this right fits nicely with the conservatism that characterizes many of those arguing for American exceptionalism. It could, therefore, be expected that Justice Breyer would support gun control and, moreover, would turn to foreign law to support this view by showing a consensus among other nations on the constitutionality of gun control. Similarly, Justice Scalia could be expected to fiercely object to gun control and to reject any reference to foreign law. However, no reference to foreign law was made, and thus, no debate over the validity of its use ensued. Indeed, at first glance, Heller seems to be an entirely internal American law debate.

\section{A. The Heller Decision}

In Heller, the Supreme Court struck down a District of Columbia law that drastically limited the ability of its residents to possess handguns. ${ }^{35}$ The majority opinion, which regarded the right to bear arms as an individual and not a collective right, concluded that the law was unconstitutional. $^{36}$ The majority opinion revolved almost entirely around the matter of the original meaning of the Second Amendment at the time of its ratification, arguing that it had included an understanding of the right to bear arms as an individual right. ${ }^{37}$ Justice Stevens's dissenting opinion also focused on original meaning but argued for the opposite understanding. ${ }^{38}$

In contrast, Justice Breyer's dissent focused on the test that would be applied for the application of the right, regardless of whether it should be understood as an individual or collective right. ${ }^{39}$ This test, he maintained, would necessarily entail the balancing of the right against the governmental interests underlying the given statute. ${ }^{40}$ This analysis, according to Breyer, would weigh four questions:

34. See, e.g., Gardbaum, supra note 23, at 407 ("[T] he United States is distinguished from other Western countries, where gun ownership is comparatively rare and tends not to be a subject that triggers - excuse the pun-the emotions." ).

35. District of Columbia v. Heller, 128 S. Ct. 2783, 2788 (2008).

36. Id. at 2797, 2821-22.

37. Id. at $2788-812$.

38. Id. at 2822-47 (Stevens, J., dissenting).

39. Id. at 2847 (Breyer, J., dissenting).

40. Id. 
$[\mathrm{H}]$ ow the statute seeks to further the governmental interests that it serves, how the statute burdens the interests that the Second Amendment seeks to protect, and whether there are practical less burdensome ways of furthering those interests. The ultimate question is whether the statute imposes burdens that, when viewed in light of the statute's legitimate objectives, are disproportionate. ${ }^{41}$

In response to Justice Breyer's position, Justice Scalia's majority opinion rejected such a balancing test for watering down constitutional rights. He stated, "The very enumeration of the right takes out of the hands of government - even the Third Branch of Government - the power to decide on a case-by-case basis whether the right is really worth insisting upon." "42 Furthermore, Scalia accused judges who use balancing of illegitimately supplementing the words of the Constitution with their views on the proper balance between rights and interests. Breyer's balancing, according to Scalia, was no more than "a judge-empowering 'interest-balancing inquiry.", 43

Justice Breyer responded to Scalia's accusations by asserting that "the very nature of the [balancing] approach - requiring careful identification of the relevant interests and evaluating the law's effect upon themlimits the judge's choices." 44 Moreover, Breyer argued that his balancing method's "necessary transparency lays bare the judge's reasoning for all to see and to criticize." 45 Finally, Breyer stated that "[c]ontrary to the majority's unsupported suggestion that this sort of 'proportionality' approach is unprecedented, the Court has applied it in various constitutional contexts." 46

\section{B. Foreign Law in Heller: The Proportionality Approach}

From the above exchange between Justices Breyer and Scalia, the debate appears to revolve solely around an internal matter of American law, seemingly echoing the age-old, uniquely American controversy over standards versus rules and balancing versus categorization. ${ }^{4}$

\footnotetext{
41. Id. at 2854 .

42. Id. at 2821 (majority opinion).

43. Id.

44. Id. at 2868 (Breyer, J., dissenting)

45. Id.

46. Id. at 2852 (citation omitted).
}

47. The debate between balancing and categorization has been especially strong in free speech jurisprudence. The first round of this debate took place in the early 1960s. See Laurent B. Frantz, The First Amendment in the Balance, 71 YALE L.J. 1424, 1449 (1962) (arguing against balancing in First Amendment jurisprudence); Wallace Mendelson, The First Amendment and the Judicial Process: A Reply to Mr. Frantz, 17 VAND. L. ReV. 479, 481 (1964) (endorsing balancing in First Amendment jurisprudence). The debate is still very much alive today. Although in the 1970s and early 1980s it disappeared somewhat, the debate has come to life again in recent years. See, e.g., Richard A. Posner, Pragmatism Versus Purposivism in First Amendment Analysis, 54 Stan. L. ReV. 737, 
However, the reference to proportionality in Breyer's dissent should immediately catch the attention of anyone versed in European and global constitutional law. This marked the first time that proportionality was used as a term of art in Supreme Court case law. Other usages of the term have been in the context of punishment, in which it bears an entirely different meaning, or in the ordinary spoken sense in referring to something as "disproportionate" or "proportionate."48 But, unlike the latter usages of the word or its derivatives in case law, Justice Breyer set the word in inverted commas and described it as an approach, thereby making it clear that the word was being used as a term of art. ${ }^{49}$ Moreover, interestingly enough, Breyer attributed the original mention of proportionality to the majority opinion, in which it actually does not appear, when he referred to "the majority's unsupported suggestion that this sort of 'proportionality' approach is unprecedented." 50 Breyer cited specific pages in the majority opinion, but the closest that any of the passages on those pages comes to what Breyer referred to is Justice Scalia's statement, "We know of no other enumerated constitutional right whose core protection has been subjected to a freestanding 'interestbalancing' approach." ${ }^{51}$ In rephrasing this passage, Breyer exchanged the

738 (2002) (endorsing balancing in First Amendment analysis); Jed Rubenfeld, The First Amendment's Purpose, 53 STAN. L. REV. 767, 770 (2001) (arguing against balancing in the context of the First Amendment). The debate also extended to constitutional law generally. See T. Alexander Aleinikoff, Constitutional Law in the Age of Balancing, 96 YAle L.J. 943 (1987); Kathleen M. Sullivan, Post-Liberal Judging: The Roles of Categorization and Balancing, 63 U. Colo. L. Rev. 293 (1992); Kathleen M. Sullivan, The Supreme Court, 1991 Term-Foreword: The Justices of Rules and Standards, 106 HARV. L. Rev. 22, 59 (1992) (describing the debate on the Court as between probalancing Justices and procategorization Justices). For a recent account of the rules versus standards debate, see Frederick Schauer, supra note 24, at 305. The debate traces back to Justice Holmes's pro-"standards" position in the late nineteenth and early twentieth centuries, see O.W. Holmes, The Path of the Law, 10 HARV. L. REV. 457, 458 (1897), versus Hart's pro-“rules" position, see H.L.A. HART, THE CONCEPT OF LAW 80 (2d ed. 1994).

48. As noted by Gardbaum, supra note 23 , at 427 n.171, reference to proportionality exists in America in the dormant commerce clause "balancing test" and in Section 5 of the Fourteenth Amendment - "is Congress's measure so disproportionate to any state violations as to go beyond remedy or prevention into 'substantive' regulation?" Id. In the context of rights, the Supreme Court has expressly rejected proportionality as part of the test for "cruel and unusual punishment" under the Eighth Amendment. Harmelin v. Michigan, 501 U.S. 957, 965 (1991).

49. Heller, $128 \mathrm{~S}$. Ct. at 2852 (Breyer, J., dissenting).

50. Id.

51. Id. at 2821 (majority opinion). 
phrase "interest-balancing" for "proportionality.", Putting proportionality in quotation marks, labeling it an approach, and replacing the majority's words are clear indicators of Breyer's conscious and intentional decision to incorporate the proportionality approach - the well-known European doctrine of proportionality - into his dissenting opinion.

Arguably, Justice Breyer was aware that most people would not notice his reference to European proportionality. Indeed, Justice Scalia apparently missed it, for he would have otherwise most likely responded to this, as he did to almost every other part of the Breyer dissent. In fact, it appears that this reference has escaped the attention of most of the commentators on Heller to date as well. But, even if Breyer's invocation of proportionality initially went unnoticed, at a later stage, Breyer or any other Justice could refer back to the passage as support for the stance that the so-called proportionality approach is not without precedent in Supreme Court jurisprudence. Breyer thus furthered the attempt to lay the groundwork for the Court's adoption, or at least recognition, of the doctrine of proportionality.

Proportionality analysis usually proceeds in three stages after a legitimate governmental end has been shown to underlie the act infringing the given constitutional right. First, the means applied must further this end; second, the government must show that it chose the least restrictive means to further that end; and third, the benefits of achieving the sought after objective must be proportionate-in a strict sense - to the extent of violation of the given right. This proportionality model has been embraced by judges in almost every Western jurisdiction outside of the United States, becoming one of the clearest features of global constitutionalism. ${ }^{53}$ The model's appeal is most likely attributable to its clear and systematic analytical formation, its combined flexibility and structure, and its seeming ability to capture the generic features of rights jurisprudence-including both means-ends analysis and balancing. Starting in the 1970s, proportionality began to spread through the Western world. The weighty influence of German constitutional law, which applied the doctrine, led to its incorporation first into the jurisprudence of the European Court of Human Rights ${ }^{54}$ and the European Court of

52. Id. at 2852 (Breyer, J., dissenting).

53. Proportionality analysis is a central feature of what Weinrib calls "the postwar paradigm." Weinrib, supra note 25, at 84; see also sources cited supra note 4 (explaining the proliferation of the proportionality paradigm).

54. See Dudgeon v. United Kingdom, 45 Eur. Ct. H.R. (ser. A) (1981), available at http://www.unher.org/refworld/docid/47fdfaf7d.html; Handyside v. United Kingdom, 24 Eur. Ct. H.R. (ser. A) (1976), available at http://www.unhcr.org/refworld/docid/ 3ae6b6fb8.html. See generally Marc-André Eissen, The Principle of Proportionality in the Case-Law of the European Court of Human Rights, in THE EUROPEAN SYSTEM FOR THE Protection of Human Rights 125, 126-31 (R. St. J. Macdonald et al. eds., 1993). 
Justice, ${ }^{55}$ and then in 1986, it traveled to Canada. ${ }^{56}$ This process sped up in the $1990 \mathrm{~s}$, at which time proportionality was adopted in almost every European country, as well as in many countries outside Europe. Today, proportionality is an accepted doctrine in Ireland, ${ }^{57}$ South Africa, ${ }^{58}$ Israel, ${ }^{59}$ Australia, ${ }^{60}$ New Zealand, ${ }^{61}$ and many more countries. ${ }^{62}$ It seems that the United States is the last system in the West to resist the appeal of the proportionality doctrine. ${ }^{63}$

Justice Breyer is likely well aware of these developments in global constitutional law and of the centrality of proportionality in other legal systems. Breyer is one of the leading American Justices in the field of comparative constitutional law and is an ambassador of sorts for the Supreme Court in other countries. Speaking fluent French, he appears regularly at international gatherings of jurists and international conferences, all of which include a fair share of proportionality analysis. ${ }^{64}$ Ultimately, Breyer's deep knowledge of comparative constitutional law, and his specific acquaintance with the doctrine of proportionality and the

55. Case 222/84, Johnston v. Chief Constable, 1986 E.C.R. 1651, 1685-87.

56. R. v. Oakes, [1986] 1 S.C.R. 103, 135-42 (Can.).

57. Blascaod Mor Teoranta v. Comm'rs of Pub. Works, [1998] I.E.H.C. 38, ๆๆ 4964 (27th February, 1998) (H.Ct.) (Ir.) available at http://www.bailii.org/ie/cases /IEHC/1998/38.html (last visited May 31, 2009).

58. Sv Zuma \& Others 1995 (2) SA 642 (CC) (S. Afr.).

59. CA 6821/93 United Mizrahi Bank Ltd. v. Migdal Coop. Vill. [1995] IsrSC 49(4) 221, 280-85, 325-31.

60. Kartinyeri v. Commonwealth (1998) 152 A.L.R. 540 (Austl.).

61. Ministry of Transp. v. Noort, [1992] 3 N.Z.L.R. 260, 282-85 (C.A.).

62. For Brazil, see Alonso Reis Freire, Evolution of Constitutional Interpretation in Brazil and the Employment of Balancing "Method" by Brazilian Supreme Court in Judicial Review 7-11 (n.d.) (unpublished conference paper, on file with author), available at http://www.enelsyn.gr/papers/w15/Paper\%20by\%20Prof\%20Alonso\%20Reis $\% 20$ Freire.pdf. For Korea, see JEON Hak-Seon, L'application du principe de proportionnalité dans la Justice constitutionnelle en Corée (n.d.) (unpublished conference paper, on file with author), available at http://www.enelsyn.gr/papers/w15/Paper\%20by \%20Prof.\%20JEON\%20Hak-Seon.pdf. Both papers were presented at the VIIth World Congress of the International Association of Constitutional Law.

63. Gardbaum, supra note 23, at 424 (proposing if "U.S. courts engage in secondstep analysis at all, they reject the near-universal proportionality test in favor of the more categorical, rule-like, fixed tiers or standards of review"); see also Vicki C. Jackson, Ambivalent Resistance and Comparative Constitutionalism: Opening up the Conversation on "Proportionality," Rights and Federalism, 1 U. PA. J. CONST. L. 583, 603 (1999) ("U.S. constitutional law does not ordinarily and explicitly resort to the idea of proportionality as a measure of constitutionality.").

64. See Salzburg Global Seminar, supra note 6; see also Richard A. Posner, Justice Breyer Throws Down the Gauntlet, 115 YALE L.J. 1699, 1715 (2006) (noting the fact that Justice Breyer is fluent in French). 
extent of its influence in Europe and elsewhere, further indicates that his reference to proportionality in Heller was not mere coincidence.

Justice Breyer's reference to foreign constitutional law in Heller is novel and unique in two ways. First, for what appears to be the first time in the ongoing foreign law debate, a foreign methodology or doctrine - and not foreign substantive ideas or solutions-was invoked. ${ }^{65}$ Because proportionality does not include any substantive commitments and instead provides only an analytical framework for rights adjudication, ${ }^{66}$ Breyer's foreign law reference in Heller stands in sharp contrast to the Roper, Atkins, Lawrence, and Grutter decisions in which the Justices who invoked foreign law did so in order to bolster their substantive conclusions regarding the interpretation of the Constitution. ${ }^{67}$ In particular, foreign law was invoked in both Roper and Lawrence as proof of consensus among members of the international community regarding standards of morality, which can constitute prima facie justification for the recognition of those standards by the Supreme Court. ${ }^{68}$

There are at least two advantages to this shift in strategy from substance to methodology. First, unlike substantive commitments, methodology seems more neutral and technical and therefore attracts less attention and criticism. Second, an imported methodological framework might prove to be even more effective than imported substantive ideas in terms of Supreme Court recognition of foreign law. A shared methodology better facilitates dialogue in future cases and could lay the foundation for the introduction of substantive ideas in the future. Indeed, the reluctance of the American judiciary to adopt proportionality analysis is an obstacle to constitutional dialogue with other legal systems. Justice Breyer therefore laid the groundwork for smoother dialogue with other countries. Indeed, the incorporation of proportionality into legal systems has often coincided with an intensified engagement in comparative constitutional law.

The second facet of the Heller reference to foreign law that distinguishes it from others is the fact that it is covert rather than overt. Justice Breyer did not directly invoke foreign constitutional law, and his

65. For a distinction between methodological and substantive forms of American exceptionalism, see Gardbaum, supra note 23, at 422-24, and Schauer, The Exceptional First Amendment, supra note 24, at 30.

66. See, for example, R. v. Keegstra, [1990] 3 S.C.R. 697 (Can.), in which Canadian Chief Justice Dickson remarks:

The analytical framework of Oakes [that is, proportionality analysis] has been continually reaffirmed by this Court, yet it is dangerously misleading to conceive of $\mathrm{s} .1$ as a rigid and technical provision, offering nothing more than a last chance Id. at 735 for the state to justify incursions into the realm of fundamental rights.

67. See supra notes 30-33 and accompanying text.

68. See supra notes $31,33$. 
opinion cited no foreign sources. ${ }^{69}$ Moreover, in two separate parts of his opinion, he made a point of stressing that his analysis rested firmly on prevailing American constitutional jurisprudence. ${ }^{70}$ This seems a clear attempt to use the term and the doctrine of proportionality without being explicit about their source. Breyer thus circumvented the criticism that usually ensues after open reliance on foreign norms, as well as the accompanying legitimacy problems. Under this approach, foreign ideas are attributed with American credentials and gain legitimacy by being presented as a natural development of American constitutional law.

Justice Breyer's approach was not, in fact, a novel strategy for incorporating foreign law into domestic constitutional law, or even for specifically incorporating the doctrine of proportionality. Indeed, in the landmark Oakes decision, which introduced proportionality into Canadian constitutional law, Chief Justice Dickson presented the doctrine as an internal Canadian constitutional legal development and as the product of interpretation of the Canadian Charter of Human Rights; he made no reference to European constitutional law, which has almost exactly the same structure of proportionality. ${ }^{71}$

Justice Breyer's awareness of the advantages inherent in covertly referencing foreign law possibly arose during a televised debate with Justice Scalia in January 2005, three years before the Heller decision. In discussing reliance upon foreign law in American jurisprudence, Scalia said to Breyer, "Look, I'm not preventing you from reading these [foreign law] cases. . . I I mean, go ahead and indulge your curiosity! Just don't put it in your opinions!"72 In Heller, then, Breyer was simply adopting

69. The only reference to foreign law was in the context of checking the correlation between gun control laws and murder rates. See District of Columbia v. Heller, 128 S. Ct. 2783, 2858 (2008) (Breyer, J., dissenting) ("[R]espondent's amici point to a statistical analysis that regresses murder rates against the presence or absence of strict gun laws in 20 European nations."); see also Brief of Criminologists et al. as Amici Curiae in Support of Respondent at 23, District of Columbia v. Heller, $128 \mathrm{~S}$. Ct. 2783 (2008) (No. 07-290), 2008 WL 383535 (citing Don B. Kates \& Gary Mauser, Would Banning Firearms Reduce Murder and Suicide?: A Review of International and Some Domestic Evidence, 30 HARV. J.L. \& PuB. POL'y 649, 651-94 (2007)).

70. Heller, 128 S. Ct. at 2847-48, 2850-51 (Breyer, J., dissenting).

71. R. v. Oakes, [1986] 1 S.C.R. 103, 136-37 (Can.). In addition, Grimm, supra note 4, 383-84, raises the question of whether Chief Justice Dickson, in writing the Oakes decision, had been guided by foreign examples or had in fact developed the test completely on his own. Grimm then notes that "[t]he German and Canadian proportionality tests differ slightly in their terminology." Id. at 384.

72. The Relevance of Foreign Legal Materials in U.S. Constitutional Cases: A Conversation Between Justice Antonin Scalia and Justice Stephen Breyer, supra note 28, 
the advice of his fellow Justice and keeping the debate behind the scenes. The Court's shift towards covert reference to foreign law also accords with what seems to be its general backing down from references to foreign legal materials. This retreat from openly referring to foreign sources, which is most likely due to the criticism it attracts, is evidenced by the fact that the Court has not referred to any foreign legal materials since the Roper case, despite having some fitting opportunities to do so. $^{73}$

There are, however, obvious disadvantages to covert use of foreign law. One is that the lack of transparency prevents debate and discussion regarding the merits of using the given norm. The rest of the discussion in this Article is thus devoted to a consideration of how the debate would have transpired among the Justices had Breyer made explicit mention of European proportionality. The aim will be to take a closer look at the Breyer claim that the Supreme Court has applied the proportionality approach "in various constitutional contexts." " Indeed, the hypothetical debate likely would have addressed the questions of precisely what adopting proportionality would entail, and how big an impact it would have on prevailing American constitutional law. In considering these questions, this Article compares European proportionality with American balancing and ultimately finds support for Breyer's claim on the doctrinal level, but difficulties in the broader context.

\section{INTRINSIC BALANCING AND BOUNDED BALANCING}

This section addresses the question of whether the general doctrinal constructs of European proportionality can be found in American constitutional law and concludes that, at least on the doctrinal level,

at 534. There is another passage in the same televised debate that illustrates a very similar point. Justice Breyer, in recounting a conversation that he had with a congressman, stated:

I said to the congressman, "If I have a difficult case and a human being called a judge, though of a different country, has had to consider a similar problem, why should I not read what that judge has said? It will not bind me, but I may learn something." The congressman replied, "Fine. You are right. Read it. Just don't cite it in your opinion." Id. at 522

73. One such obvious opportunity to cite foreign legal materials was Kennedy $v$. Louisiana, which ruled that it is unconstitutional to impose the death penalty for the crime of raping a child. $128 \mathrm{~S}$. Ct. 2641, 2675-77 (2008). The decision turned over the same legal questions that were posed in the Roper case-determining the evolving standards of morality regarding the Eighth Amendment's Cruel and Unusual Punishment Clause-yet, unlike his decision in Roper, Justice Kennedy, who wrote the majority opinion, did not cite to any foreign legal material.

74. Heller, $128 \mathrm{~S}$. Ct. at 2852 (Breyer, J., dissenting). 
Breyer might have had a valid point in Heller. ${ }^{75}$ However, taking into account the historical, cultural, and institutional characteristics of America and Europe, balancing and proportionality are situated in significantly different ways.

\section{A. Balancing and Proportionality: Doctrinal Similarities and Beyond}

Conceptually, balancing and proportionality seem to be distinct doctrines with different connotations. Proportionality seems to set out by first considering one object and then asking whether another object is proportional to that first object. Balancing, in contrast, seems to lack any similar sense of a starting point; rather, it compares two objects without according any preference to either one. ${ }^{76}$ However, this conceptual difference is of minor practical import because the two doctrines involve very similar thought processes: both assess the extent of rights infringement and the relative necessity of the infringement for realizing state interests.

As with European proportionality, in American constitutional law, balancing the comparative importance of the infringed right with the governmental interests comes after conducting the tests to filter out superfluous government means. In American law, these tests-which comprise the first and second prongs of European proportionality-are conglomerated into the well-known least restrictive means test, which is associated with balancing. Recall that there are three stages to proportionality: the first two stages-rational connection and least restrictive means - entail a means-ends analysis, while the third step is a balancing test that contemplates proportionality in its strict sensebalancing the benefits against the costs. Arguably, all three stages of the proportionality analysis exist in American constitutional law. As to the first two stages of proportionality, which concern means-end analyses, they exist explicitly in the well-known levels of scrutiny tests, which are

75. Although this Article sides with a revisionist approach regarding the difference in terms of one-step analysis versus two-step analysis, this support is limited to the specific context of this aspect; it does not extend to other structural and nonsubstantive differences. For example, Part II argues that there is a strong difference between the American and European constitutional systems in terms of positive versus negative rights and the application of constitutional rights in the private sphere.

76. For an overview of the use of the scales metaphor, see Dennis E. Curtis \& Judith Resnik, Images of Justice, 96 Y ALE L.J. 1727, 1741 n.32 (1987). 
applied in different degrees of rigorousness in American constitutional law. Basically, the same two questions that proportionality weighs are being asked in the American tests as well: whether the means taken by the government further a governmental end, and whether they are the least restrictive means by which the government can pursue that goal. ${ }^{77}$ The balancing test that is the third stage of proportionality is present both implicitly in the least restrictive means requirement and explicitly in many different direct applications of balancing, ${ }^{78}$ which occur in contexts ranging from low-level speech, to the commerce clause, to due process. $^{79}$

Notwithstanding these similarities between European and American legal analysis, proportionality is arguably unique in that it consolidates the aforementioned analytical elements in an orderly and consecutive manner under the umbrella of one doctrine. If this is indeed the case, Justice Breyer's introduction of proportionality is no more than an ordering and organizing of preexisting components of American constitutional law. Thus, although an undeniably important move in itself, Breyer's approach does not amount to creating something new, and instead supports a general argument, such as that made by David Law, that a generic constitutional law structure exists in every constitutional system, including American constitutional law. ${ }^{80}$

Therefore, at the doctrinal level, Justice Breyer and critics of American exceptionalism are correct in claiming that the proportionality approach is at least latently present in American constitutional law. The doctrinal level, however, does not paint the entire picture. There are real differences in the ways these similar doctrines function and in the meanings they are assigned, as well as in the respective attitudes towards them in America and elsewhere. This conclusion accords with several comparative scholars who have argued for a more contextual approach in comparative constitutional law. Mark Tushnet and Pierre Legrand, amongst others, have strongly advocated for such contextualism,

77. Richard H. Fallon, Jr., Strict Judicial Scrutiny, 54 UCLA L. REV. 1267, 1336 (2007).

78. Id. at 1306-08; Guy Miller Struve, The Less-Restrictive-Alternative Principle and Economic Due Process, 80 HARV. L. ReV. 1463, 1463-64 (1967); Note, Less Drastic Means and the First Amendment, 78 YALE L.J. 464, 468 (1969).

79. Aleinikoff, supra note 47, at 963-67 (documenting the spread of balancing in American constitutional law); see also Ian Ayres \& Sydney Foster, Don't Tell, Don't Ask: Narrow Tailoring After Grutter and Gratz, 85 TEX. L. REV. 517 (2007) (discussing the use of balancing in affirmative action cases).

80. Law, supra note 4, at 659. 
warning against facile comparisons that do not take into account deeper constructs of cultures, institutions, and attitudes. ${ }^{81}$

In another essay, we addressed the historical differences between balancing and proportionality. A comparative historical account of the different purposes and ends of balancing in American constitutional law and proportionality in European constitutional law suggests that proportionality was used in nineteenth-century Germany to introduce rights into a system lacking constitutional protections, whereas balancing was developed in the United States in the early twentieth century to limit rights accorded absolute protection by the Lochner Court. ${ }^{82}$ This Article presents a related account of the development of the two doctrines, emphasizing political culture and the respective conceptions of the polity in the two systems. This account reveals that proportionality in Germany is based on an organic conception of the state and operates to moderate and navigate the realization of commonly shared social values and interests. In the United States, greater public suspicion of the Court and government has led to a more minor and subsidiary role for balancing, bounded by a more categorical approach towards rights. Balancing in America is instrumental in smoking out illicit motives, serves as proxy for a categorical approach, and when true balancing does take place, is subsidiary and applied in a pragmatic fashion. Thus, German proportionality and the American doctrine of balancing represent two types of balancing: the latter the bounded sense of balancing and the former intrinsic balancing.

\section{B. The Intrinsic Sense of Balancing in Germany}

This Article focuses on Germany as reflecting European proportionality for two reasons. The first and more obvious reason is that Germany is

81. See, e.g., Pierre Legrand, European Legal Systems Are Not Converging, 45 INT'L \& COMP. L.Q. 52, 55-60 (1996); Mark Tushnet, The Possibilities of Comparative Constitutional Law, 108 Yale L.J. 1225, 1300 (1999); Mark Tushnet, Some Reflections on Method in Comparative Constitutional Law, in THE MigRation OF COnSTITUTIONAL IDEAS, supra note 25, at 67,81 (arguing for a combination of the universal and contextual approaches in comparative constitutional law; the universal approach allows us to understand which of the legal arrangements constitute a false necessity, whereas the contextual approach reminds us that constitutional law is deeply embedded in the cultural, doctrinal, and social contexts of each country).

82. Iddo Porat \& Moshe Cohen-Eliya, American Balancing and German Proportionality: The Historical Origins 13, 26 (Sept. 23, 2008) (unpublished paper), available at $\mathrm{http}: / /$ papers.ssrn.com/sol3/papers.cfm?abstract_id=1272763. 
where the doctrine originated. ${ }^{83}$ The second reason is the tremendous influence of German constitutional law in general and its application of proportionality in particular, due to the fact that decisions of the Federal Constitutional Court are cited in the decisions of many other legal systems across the globe. ${ }^{84}$ The German conception of balancing revolves around intrinsic values. Balancing expresses values of compromise, mediation, and pluralism. This intrinsic sense of balancing is tied to an organic conception of the state, under which all organs trust one another and cooperate to realize common values that express the spirit of the nation.

\section{The German Organic Conception of the State}

The terrible outcome of the Second World War ignited a debate over the political morality that should guide the constitution of the new Germany. In his seminal work The German Idea of Freedom, Leonard Krieger argued that in light of the moral bankruptcy of nationalism, Germany should depart from its communitarian heritage and adopt a more neutral, suspicion-based constitution, one that guaranteed negative liberties for all its citizens and set strict limits on the government. ${ }^{85}$

83. The first reference to proportionality can be found in the Allgemeines Landrecht, the Prussian General Code of 1794, which authorized the government to exercise police powers in order to ensure public order, but at the same time also limited those powers to such measures that are essential for achieving that goal. The pertinent section stated that "the police is to take the necessary measures for the maintenance of public peace, security and order." ALLGEMEINES LANDRECHT FÜR DIE PREUßISCHEN StaAten von 1794 [Prussian General CoDe], pt. II, tit. 17, § 10, translated in Stone Sweet \& Mathews, supra note 4, at 101 (emphasis added). The principle of proportionality was developed in the writings of nineteenth-century German constitutional scholars and became judicial doctrine in the Prussian Supreme Administrative Court (1882-1941). See Kenneth F. Ledford, Formalizing the Rule of Law in Prussia: The Supreme Administrative Law Court, 1876-1914, 37 CENT. EUR. HIST. 203, 222 (2004); see also Stone Sweet \& Mathews, supra note 4, at 97-111 (providing discussions on Germany).

84. Jeffrey B. Hall, Taking "Rechts" Seriously: Ronald Dworkin and the Federal Constitutional Court of Germany, 9 GERMAN L.J. 771, 771 (2008), http://www. germanlawjournal.com/pdf/Vol09No06/PDF Vol 09 No 06 771-98 Articles Hall.pdf ("Over the past 60 years the German Basic Law has become one of the most influential constitutional systems in the world."). Hall makes reference to Juliane Kokott, From Reception and Transplantation to Convergence of Constitutional Models in the Age of Globalization - with Special Reference to the German Basic Law, in CONSTITUTIONALISM, Universalism, AND DEMOCRACY - A COMPARATIVE ANALYSIS 71 (Christian Starck ed., 1999), which catalogs and analyzes the extensive reception of the German Basic Law in constitutions throughout the world, and Donald P. Kommers, Germany: Balancing Rights and Duties, in INTERPRETING CONSTITUTIONS: A COMPARATIVE STUDY 161, 16162, 201-02 (Jeffrey Goldsworthy ed., 2006).

85. LEONARD KRIEGER, THE GERMAN IdEA OF FreEdom 470 (1957) (arguing for a position that "views the state as a morally neutral, purely utilitarian organization of public power"); see also DONALD P. KOMMERS, THE CONSTITUTIONAL JURISPRUDENCE OF 
Although sound at first glance, it appears that this "American-style" solution of state neutrality and negative rights was inappropriate for post-World War II Germany. First, adhering to state neutrality would also entail neutrality towards the racist attitudes that were prevalent in a society in which the large majority of the population was raised on the value of Aryan superiority. Indeed, an ambitious project lay behind the formulation of the postwar German constitution: the goal was to bring about a profound transformation of German consciousness and attitudes such that the values upon which human rights are based would become acknowledged and internalized. ${ }^{86}$ This aim could only be realized by according the state a nonneutral stance in society. Secondly, the "neutral" approach does not conform to traditional German political theory, which is Hegelian and Aristotelian in orientation. Under this tradition, the state is not conceived as merely an aggregate of individuals who live in a given territory and coordinate their activities by means of the state, but instead as a union of people who have a shared system of values and endeavor to promote them. ${ }^{87}$ Rather than the atomized conception of the

THE FEDERAL Republic OF Germany 33 (2d ed. 1997); Girish N. Bhat, Recovering the Historical Rechtsstaat, 32 REV. CENT. \& E. EUR. L. 65, 88-89 (2007).

86. See Clemens Jabloner, Hans Kelsen: Introduction, in WEIMAR: A JURISPRUDENCE OF CRISIS 67, 73 (Arthur J. Jacobson \& Bernhard Schlink eds., Belinda Cooper et al. trans., 2000) (arguing that the concepts of formal democracy and neutrality that guided the Weimar Republic were reasons for its constitutional collapse); Donald P. Kommers, German Constitutionalism: A Prolegemenon, 40 EMORY L.J. 837, 852-53, 861 (1991) (explaining that the trauma of the Second World War has led many German theorists to suggest a departure from neutral principles of formalism and to adopt a natural law approach).

87. The German fundamental concept of the Rechtsstaat-"a state governed by law"- differs from the common law concept of rule of law, in that it is tied to an organic conception of the state that seeks to integrate state and society. See KommERS, supra note 85 , at 36; HANS RoSENBERG, POLITISCHE DENKSTRÖMUNGEN IM DEUTCHEN VORMÄRZ 37 (1972) (arguing that the state is viewed not only as an institutional safeguard to protect individual rights, but also as "Vaterland"); RUDOLF SMEND, VERFASSUNG UND VERFASSUNGSRECHT (1928) (stating the role of the constitution and of constitutional interpretation is to integrate society around shared values); OTTO VON Gierke, The Development of Political Theory (Bernard Freyd trans., Howard Fertig, Inc. 1966) (1939) (original German version appeared in 1880); Mathias Reimann, Nineteenth Century German Legal Science, 31 B.C. L. REV. 837 (1990) (discussing the influence of Hegelian and communitarian ideas on nineteenth-century German legal science). On Smend's influential integration theory, see also Stefan Korioth, Rudolph Smend: Introduction, in WEIMAR: A JURISPRUDENCE OF CRISIS, supra note 86, at 207. 
self, the German political theory of the "separateness of the person" 88 emphasizes that a person is embedded in a community that shares common values and expresses solidarity towards all members of that community. Accordingly, in 1954, the Federal German Constitutional Court (FGCC) ruled that:

The Basic Law's idea of man is not the idea of an isolated sovereign individual; rather, the Basic Law has decided the tension between individuals and society in favor of the individual being community related and community bound - while not touching its intrinsic value. ${ }^{89}$

State organs therefore play an important role in realizing common values. Naturally, such an organic conception of the state is trustoriented: It is constructed on a premise of reciprocal cooperation and trust amongst all state organs and assumes that all state organs have legitimate interests that should be optimized. The functioning of the FGCC should be understood in light of this organic conception. Unlike the U.S. perception of courts, constitutional judges in Germany are not expected to fulfill a classic antimajoritarian task. As Alec Stone Sweet explains, in Germany, as in Europe in general, the Constitutional Court does not conduct judicial review in the typical antimajoritarian sense that many Europeans oppose. Instead, the court is viewed as a political organ that constitutes an integral part of the state and shares with the state the task of elaborating and shaping social values and norms. ${ }^{90}$ This conception of the court's role, which reflects and derives from the organic approach to the state, may account for the fact that, in Germany, there is much less criticism of judicial review for being countermajoritarian. ${ }^{91}$

88. The concept of the separateness of the person is central in liberalism and in libertarianism. See Robert NozICK, ANARChy, StATE, AND UtOPIA 32-33 (1974); JoHN RAWLS, A THEORY OF JUSTICE 27 (1971).

89. Bundesverfassungsgericht [BVerfG] [Federal Constitutional Court] July 20, 1954, 4 Entscheidungen des Bundesverfassungsgerichts [BVerfGE] 7 (ণ 15-16) (F.R.G.) (author's translation), available at http://www.servat.unibe.ch/dfr/bv004007.html.

90. Alec Stone Sweet, Governing with Judges: Constitutional Politics in EUROPE 32, 40 (2000).

91. It is true that, in the $1960 \mathrm{~s}$, there was some criticism of the broad role of the court and its extensive reference to abstract values. Carl Schmitt and other German legal scholars have attacked the Constitutional Court on the grounds that it leads to the "tyranny of values" ("die tyrannei der werte"), primarily because values are of an abstract nature and their realization quite often leads to rulings that are in accordance with the particular judge's own personal value system. See ERNST ForsthOFf, Zur Problematik der Verfassungsauslegung 19, 40 (1961); Carl Schmitt, Die Tyrannei der Werte, in SÄKULARISATION UND UTOPIE: ERNST FORSTHOFF ZUM 65. GEBURTSTAG 37, 39 (K. Doering \& W.G. Greve eds., 1967); Wolfgang Zeidler, Grundrechte und Grundentscheidungen der Verfassung im Widerstreit, in VERHANDLUNGEN DES DREIUNDFÜNFZIGSTEN DEUTSCHEN JURISTENTAGES 6, 6-29 (1980). This criticism, however, represents the minority stance in current German legal scholarship. See Kommers, supra 
As Dieter Grimm has put it, "There is no preestablished difference between court and legislatures which a particular contribution has to adopt and which an interpreter has to enforce regardless of what the constitution says. In addition, constitutional courts inevitably cross the line between law and politics." 92

Shortly after its establishment, the FGCC ruled that the constitution is governed by an objective and hierarchal set of values, the so-called Objective Wertrangordnung. ${ }^{93}$ This ruling did not mark a departure in any way from traditional German thought, which assigns the state a central role in realizing individual well-being and integrating individuals into a community with shared values. The court did, however, change the contents of those common values in its ruling. Rather than nationalistic values - such as Volksgeist, or "the spirit of the people," which lay at the foundation of nineteenth-century German jurisprudence ${ }^{94}$ - the court deemed the dominating value of German society to be human dignity. ${ }^{95}$ This value, which now opens the German constitution, is absolute and constitutes the constitution's Archimedes Point. ${ }^{96}$

note 86 , at 842 (stating that "the source and authority of the Federal Constitutional Court are relatively undisputed").

92. KOMMERS, supra note 85, at 44 (referencing Grimm's comments that appear in Dieter Grimm, Comment, in CONSTITUTIONAL REVIEW AND LEGISLATION: AN INTERNATIONAL COMPARISON 169, 169 (Christian Landfried ed., 1988)).

93. Article 117 Case, Bundesverfassungsgericht [BVerfG] [Federal Constitutional Court] Dec. 18, 1953, 3 Entscheidungen des Bundesverfassungsgerichts [BVerfGE] 225 (232) (F.R.G.) (author's translation), cited in KOMMERS, supra note 85, at 47-48 (noting that the Constitutional Court rejected "value-free legal positivism" and that the Court in the first years "appeared to accept natural law as an independent standard of review").

94. Reimann, supra note 87, at 853. To Savigny, one of the leading legal scholars in nineteenth-century Germany, Volksgeist does not stand for "culture" in the anthropological sense, but rather in the intellectual sense; Volksgeist was the organic development of the law's intellectual underlying principles. Id.

95. Article 1(1) of the German Basic Law, 1949, provides: "Human dignity shall be inviolable. To respect and protect it shall be the duty of all state authority." GRUNDGESETZ [GG] [Constitution] art. 1(1) (F.R.G.), available at http://www.bundestag. de/interakt/infomat/fremdsprachiges_material/downloads/ggEn_download.pdf (English translation). In the Microsenzus case, Bundesverfassungsgericht [BVerfG] [Federal Constitutional Court] July 16, 1969, 27 Entscheidungen des Bundesverfassungsgerichts [BVerfGE] 1 (F.R.G.), the FGCC ruled that "[h]uman Dignity is at the very top of the value order of the Basic Law." Id. (author's translation).

96. Kommers, supra note 86 , at 855. 


\section{Proportionality as an Intrinsic Element of the Organic Conception of the State}

In addition to being closely tied to the German organic conception of the polity, the doctrine of proportionality is widely conceived as the main tool by which the organic conception is realized in the jurisprudence of the Federal Constitutional Court. Proportionality in Germany is not only a conflict-resolving means, but it is also applied to harmonize and integrate the various state organs around shared values. ${ }^{97}$ German constitutional scholars do not speak of proportionality in terms of a pragmatic enterprise involving some sort of cost-benefit analysis. Rather, they take a more idealistic view of the doctrine, as necessary for the optimization of values. ${ }^{98}$ Proportionality thus serves as the primary methodology for maintaining the integrity and "unity of values" of the Basic Law. ${ }^{99}$ As first stated by Konrad Hesse, the late Constitutional Court justice:

The principle of the constitution's unity requires the optimization of [values in conflict]: Both legal values need to be limited so that each can attain its optimal effect. In each concrete case, therefore, the limitation must satisfy the principle of proportionality; that is, they may not go any further than necessary to produce a concordance of both legal values. ${ }^{100}$

Proportionality, which is also closely related to the principle requiring harmonic interpretation of the German constitution, or "praktische Korkordanz," 101 thus functions as a central mechanism for enhancing harmony and cooperation between conflicting values in the German society. The fact that proportionality serves to ensure the realization of abstract constitutional values and makes them meaningful in concrete cases traces back to the German conception of value order. Conflicts in Germany are perceived as transpiring entirely within the constitutional sphere-both interests and rights derive from the constitution. The main concern of proportionality, then, is to determine which of the interests or

97. GrundGeSETZ: Kommentar 94, 95 (Michael Sachs ed., 1996).

98. See Kommers, supra note 85, at 46-47; KonRad Hesse, GrundzÜGe DES VerfassungsRechts DER BundesRepublik DeutChland 27 (1988), translated in Kommers, supra note 86 , at $851 \mathrm{n} .43$.

99. In the Southwest State case, Bundesverfassungsgericht [BVerfG] [Federal Constitutional Court] Oct. 23, 1951, 1 Entscheidungen des Bundesverfassungsgerichts [BVerfGE] 14 (F.R.G.), the court first set the "unity of values" principle and held that "every constitutional provision must always be interpreted in such a way as to render it compatible with the fundamental principles of the constitution." Id. (author's translation).

100. HESSE, supra note 98, at 27, quoted and translated in KOMMERS, supra note 85 , at 46.

101. Id. at 30-31. 
rights in conflict best further the ultimate shared goals of the constitutional order. In addition, as noted, the organic conception of the polity makes the policymaking aspects of proportionality less problematic in the German constitutional regime, and it is the Constitutional Court's manifest task to instantiate the abstract values of the constitution in particular cases. Thus, rather than being perceived as illegitimate judicial intervention in policymaking, balancing is viewed in Germany, and elsewhere on the Continent, as the objective, systematic, and logical implementation of constitutional rights, while realizing values in everyday life is considered to be the quintessential task of the court. ${ }^{102}$

The centrality of the doctrine of proportionality in Constitutional Court jurisprudence is evidenced clearly in its ruling that proportionality emerges "basically from the nature of constitutional rights themselves." Indeed, Robert Alexy has gone so far as to assert that proportionality "logically follows from the nature of [rights as] principles; it can be deduced from them." 104 Thus, the doctrine of proportionality is understood in Germany as inherent to the constitution, despite the absence of any explicit reference to it therein. ${ }^{105}$

Two Constitutional Court cases are illustrative of how proportionality analysis operates in light of the organic conception of the state. In Mephisto, the court dealt with the constitutionality of a judicial order banning the distribution of Klaus Mann's Mephisto, on the grounds that it slandered the reputation of a deceased Nazi collaborator. ${ }^{106}$ In

102. Jacco Bomhoff, Lüth's 50th Anniversary: Some Comparative Observations on the German Foundations of Judicial Balancing, 9 GERMAN L.J. 121, 124 (2008), http://www.germanlawjournal.com/pdf/Vol09No02/PDF_Vol_09_No_02_121-124_Articles_ Bomhoff.pdf.

103. Bundesverfassungsgericht [BVerfG] [Federal Constitutional Court] Dec. 15, 1965, 19 Entscheidungen des Bundesverfassungsgerichts [BVerfGE] 342 (348) (F.R.G.) (author's translation).

104. Robert Alexy, A Theory of Constitutional Rights 66 (Julian Rivers trans., 2002).

105. In most post-World War II constitutional and international documents, there is an explicit textual basis for proportionality analysis. See Grimm, supra note 4, at 38384 (noting that, in the case of the Canadian Charter of Rights and Freedoms, "proportionality appears to be a genuine interpretation of the words 'reasonable limits . . . as can be demonstrably justified in a free and democratic society"'). In Germany, however, the constitutional text lacks such explicit reference. The Constitutional Court derived the principle of proportionality from the Rechtsstaat but without explaining why. See id. at 385.

106. Mephisto case, Bundesverfassungsgericht [BVerfG] [Federal Constitutional Court] Feb. 24, 1971, 30 Entscheidungen des Bundesverfassungsgerichts [BVerfGE] 173 
balancing the right to reputation and free artistic speech, the court deliberated which of the conflicting values had the stronger link to the paramount value of human dignity. ${ }^{107}$ The court's decision in favor of the right to reputation - and to ban the book's distribution - meant that the balancing process more strongly promoted the German value order that prescribed "man as an autonomous person who develops freely within the social community."

A more nuanced application of proportionality analysis can be found in the Lebach decision. ${ }^{109}$ In Lebach, the court addressed the question of whether a television station could broadcast a documentary exposing the sexual orientation of a prisoner who was about to be released. ${ }^{110}$ The court weighed the extent to which the broadcast would harm the right to privacy and the extent of harm to free speech that would ensue from banning the program in light of the paramount value of human dignity. ${ }^{111}$ This time, however, the court stressed that it would not abstractly rank the competing rights. ${ }^{112}$ Rather, the process of mediation and harmonization between rights must take place on an ad hoc basis, with respective extents of harm measured in light of the circumstances of each given case. ${ }^{113}$ As a result, the court ruled that banning the reference to the prisoner's sexual orientation in the broadcasting would better realize the supreme value of human dignity. ${ }^{114}$

Ultimately, it appears that proportionality analysis in Germany has four distinct intrinsic features. First, primary focus is placed on the balancing stage - proportionality in its strict sense - rather than on the identification of the governmental goal or the means-ends analysis. ${ }^{115}$ Hence, balancing enjoys a central status in German constitutional law. Second, when conducting balancing analysis, the Constitutional Court considers which of the competing rights or values better optimizes the constitutional value order and, more specifically, which one more

(F.R.G.), available at http://www.servat.unibe.ch/dfr/bv030173.html, summarized and partially translated in KOMMERS, supra note 85, at 301-04.

107. Id.

108. Id.

109. Lebach case, Bundesverfassungsgericht [BVerfG] [Federal Constitutional Court] May 2, 1973, 35 Entscheidungen des Bundesverfassungsgerichts [BVerfGE] 202 (F.R.G.), available at http://www.servat.unibe.ch/dfr/bv035202.html, summarized and partially translated in KOMMERS, supra note 85, at 416-19.

110. Id.

111. Id.

112. Id.

113. Id.

114. Id.

115. Grimm, supra note 4, at 393 (stating that " $[\mathrm{t}]$ he most striking difference between [Canada and Germany] is the high relevance of the third step of the proportionality test in Germany and its more residual function in Canada"). 
strongly upholds the paramount value of human dignity. Third, German balancing is always conducted in an ad hoc manner. In Germany, this does not raise any issue of judicial legitimacy because, under the organic conception of the state, it is actually the court's duty to realize these values in concrete cases. Finally, this German model of intrinsic balancing presupposes that everything is in the constitution, and that there are no clear-cut distinctions between rights and interests or a priori preferences for either. ${ }^{116}$

\section{The Bounded Sense of Balancing in America}

Immediate important differences can be identified between German and American political cultures, which in turn impact the way that balancing is conceived and applied in America as opposed to the conception and application of proportionality in Germany. In contrast to the German organic conception of the state and broad understanding of rights with no distinction between rights and interests, American constitutional culture holds a more traditional view of rights as strong trumps or side constraints vis-à-vis government action. The American approach, which is the result of the great suspicion with which both government and the judiciary are regarded, clearly undermines the validity of balancing in America because balancing erodes the distinctiveness of rights versus interests and assigns courts broad discretion. Historically, balancing entered the American legal system through the sphere of private law, where a clear-cut distinction between rights and interests was deemed conceptually problematic. ${ }^{117}$ Balancing only later spread to constitutional law, where it was initially used mainly to criticize, rather than bolster, judicial review. ${ }^{118}$ These shaky beginnings continue to frame the use of balancing in American constitutional law. Thus, even as balancing has become a common phenomenon in American jurisprudence, it is still bounded, so to speak, by the narrow and categorical American

116. Kumm, supra note 4, at 165 (stating that, in Germany, rights are not conceived of as "trumps" or even "shields"); Julian Rivers, A Theory of Constitutional Rights and the British Constitution, in A THEORY OF CONSTITUTIONAL Rights, supra note 104, at xvii, xxxv-xxxvi (indicating that Alexy's theory does not differentiate between rights and interests in that both are subject to the requirement of optimization, that is, to proportionality analysis).

117. See Porat \& Cohen-Eliya, supra note 82, at 20.

118. The concept of balancing was used to criticize judicial review during the Lochner era. Judicial review during that period was based on a clear separation between rights and interests, and balancing was used to attack this approach. See id. at 26-27. 
conception of rights, thereby remaining distinct from the intrinsic conception of balancing in Germany.

\section{The Suspicion-Based Conception of the State in America}

Four key features of American constitutional law are clearly indicative of the suspicion-based American approach to the state: (1) the separation of powers scheme; (2) the conception of rights as trumps; (3) the notion of neutrality; and (4) the democratic conception of the Constitution.

First, in contrast to the German organic conception of the state, the American conception of the state is characterized by a well-known distrust of government, deriving from the idea of individual autonomy and self-rule. ${ }^{119}$ This distrust extends to all branches of government, including the judiciary, and lies at the base of the particularly American emphasis on separation of powers: ${ }^{120}$ because no institution can be trusted not to overstep its legitimate bounds, power must be decentralized by clearly defining the limits of each branch of government and clearly separating them. ${ }^{121}$ Consequently, American constitutional culture focuses on setting limits on judicial power and distinguishing the judicial role from the roles of the other branches of government. ${ }^{122}$ This, of course, stands in stark contrast to the conception of the German Constitutional Court as operating between the lines of politics and law.

Second, American constitutionalism is based on the conception of rights as trumps. The American culture of distrust also bred a suspicionbased approach to drafting the Constitution-clear rules for government and clear rights for citizens were crafted as a way of limiting government power. That is, formulating constitutional rights in absolute terms was preferred to the complexity of allowing limitations on rights in some instances, and a clear-cut distinction between individual rights and governmental interests was preferred to blurred boundaries in order to safeguard individual autonomy and to constrain governmental power. ${ }^{123}$

119. The most distinct exposition on the centrality of distrust in American political culture can be found in JOHN HART ELY, DEMOCRACY AND DiSTRUST 102-03 (1980).

120. See, for example, Rachel Barkow describing the American governmental system as one "whose hallmark is supposed to be the separation of powers," in Rachel E. Barkow, Institutional Design and the Policing of Prosecutors: Lessons from Administrative Law, 61 STAN. L. REV. (forthcoming Feb. 2009), available at http://ssrn.com/ abstract $=1114172$.

121. See, e.g., CAss R. Sunstein, The Partial Constitution 21 (1993) (explaining the intention of the framers that "[i]n a large republic, the various factions would offset each other").

122. See, e.g., AleXander M. Bickel, The Least Dangerous Branch 46-47 (1962).

123. C. Edwin Baker, Limitations on Basic Human Rights-A View from the United States, in The Limitation of Human Rights in Comparative Constitutional Law 75, 
Third, diverging from the German conception of underlying values, the American concept of the polity is based on the Lockean notion of state neutrality and individual liberties. ${ }^{124}$ Developed in a historical period marked by the persecution of religious minorities in Europe, American constitutionalism seeks to allow maximum freedom for personal beliefs, and places significant value on allowing multiple and even conflicting ideologies to coexist within a shared political system. The Constitution supplies the infrastructure for democracy, but ideas and ideologies must not be governed or imposed through the Constitution; they must be hashed out through the democratic process. According to Justice Holmes, the Constitution should enable people with extremely divergent views to be united under its umbrella. ${ }^{125}$

Finally, American constitutional law is based on a deep belief in representative democracy and the sovereignty of the people. Since Marbury v. Madison, ${ }^{126}$ judicial review and the upholding of the Constitution have been justified by the democratic principle of self-rule. ${ }^{127}$ That is, the Constitution represents a particularly long-lasting and fundamental means of democratic self-legislation; it represents the particular commitments that the American people undertook and set as higher law. This conception of democratic self-rule-more so than the organic conception of the state-views the constitutional text that incorporates these commitments as of ultimate importance.

76, 89 (Armand de Mestral et al. eds., 1986) (describing the American categorical approach to rights as opposed to approaches that expressly allow for the limitation of rights).

124. There is wide consensus on the significant influence of Lockean philosophy on the American Bill of Rights, though there is dispute as to the centrality of the right to property - as manifested in Locke's writings - in the American Constitution. See, e.g., Richard EPsteIn, TAKIngS: PRIVATE Property AND THE POWER OF EMINENT DOMAIN 17, 29 (1985); cf. Herman Schwartz, Property Rights and the Constitution: Will the Ugly Duckling Become a Swan?, 37 AM. U. L. REV. 9, 14-19 (1987) (questioning the strength of Locke's influence on the founding fathers).

125. See Justice Holmes's famous statement in his dissent for Lochner v. New York, 198 U.S. 45 (1905): “[A] constitution is not intended to embody a particular economic theory, whether of paternalism and the organic relation of the citizen to the State or of laissez faire. It is made for people of fundamentally differing views." Id. at 75-76 (Holmes, J., dissenting).

126. 5 U.S. (1 Cranch) 137 (1803).

127. See, for example, Jed Rubenfeld arguing that what distinguishes American constitutionalism is the conception of the Constitution as "the people's self-given law." Rubenfeld, supra note 19, at 2000. 


\section{The Suspicion-Based Conception of the State and Bounded Balancing}

Whereas under an organic conception of the state balancing is central to the judicial task of collaborative enhancement of values, it is a problematic mechanism under a suspicion-based conception. First, the separation of powers doctrine and public wariness of the courts clash with balancing because it entails a considerable amount of judicial discretion, greater, at any rate, than that required by a rule-bound or categorical approach. ${ }^{128}$ Moreover, balancing appears to be almost inseparable from policymaking, which is a function assigned to the elected branches of government; this further infringes on the idea of separation of powers. ${ }^{129}$ Second, balancing also presents a problem from the perspective of the conception of rights as trumps: obscuring the distinction between rights and interests and allowing for rights to be more easily set aside due to state interests result in weaker limits on government. ${ }^{130}$ Third, judicial balancing undermines the neutrality value, for it entails substantive assessments of values by the Court as well as decisions on the appropriate resolution of conflicts between values. And finally, balancing tends to prevent textual analysis because balancing is forward looking and involves consequentialist rather than interpretative questions. ${ }^{131}$

128. Burt Neuborne argues that "judicial balancing has been subjected to deserved academic criticism . . . because it licenses a judge to engage in overtly subjective decision-making that replicates and occasionally displaces, identical thought-processes already carried out by a politically responsible official." Burt Neuborne, Notes for a Theory of Constrained Balancing in First Amendment Cases: An Essay in Honor of Tom Emerson, 38 CASE W. RES. L. REV. 576, 578 (1988).

129. Thus, Ducat argues, "The approach to judicial decision-making, taken by interest balancers, is much like that taken by political actors staffing coordinate institutions of government who must themselves choose between rival group interests on issues of the day." CRAIG R. DUCAT, MODES OF CONSTITUTIONAL INTERPRETATION 119 (1978). Ducat continues, "[W]e need to know how the [balancing] technique of judicial review differs from legislative interest balancing," and whether the principled quality of the judicial process can be sustained at all with interest balancing. Id. at 133 .

130. See Ronald DwORKIN, TAKING Rights SERIOUSLY 198 (1977) ("The metaphor of balancing the public interest against personal claims is established in our political and judicial rhetoric, and this metaphor gives the model both familiarity and appeal. Nevertheless, the model is a false one . . .."); see also Ronald Dworkin, Comment, It Is Absurd to Calculate Human Rights According to a Cost-Benefit Analysis, GUARDIAN (London), May 24, 2006, (Debate \& Comment), at 28.

131. Laurent Frantz, who strongly objected to balancing in free speech during the 1960 s, maintained that instead of treating the Constitution as a higher law and applying it to the political organs, balancing treats the Constitution as if it were no law at all and simply allows the Court to second guess the wisdom, rather than the legality, of certain governmental decisions. Frantz, supra note 47, at 1433, 1441, 1443; cf. Jackson, supra note 4 , at 843 (arguing with regard to proportionality that it "may have little or no role on 


\section{Bounded Balancing}

As a result of the skepticism with which balancing is treated and its clash with some of the basic tenets of American constitutionalism, its status in American constitutional law differs greatly from its status in German law. In Germany, balancing stands front and center as a constitutional doctrine in the proportionality framework, while in America, it is generally assigned a more residual and instrumental role and is bounded by the categorical approach-hence its classification as "bounded balancing."

Precisely how American balancing is bounded can be illustrated by analogy to a typology proposed by Richard Fallon regarding the doctrine of strict scrutiny. ${ }^{132}$ Following Fallon, the proceeding sections identify three types of balancing in American constitutional case law. The first is balancing as smoking out. In this sense, balancing is an evidentiary tool used to smoke out a hidden illicit governmental motive. This is termed instrumental balancing as distinguished from German balancing, which is attributed with intrinsic value. The second type is balancing as an exception to the rule. Here, balancing is a tool for maintaining categorical protection of rights by allowing for the balancing of rights against interests in exceptional cases of extraordinary circumstances. This is termed residual balancing because balancing is conducted only as the exception. Third, there is true balancing. Even in instances of true balancing, as opposed to exceptional cases, it is applied in a pragmatic fashion, which differs substantially from the more idealistic and formalistic style of German proportionality.

\section{a. Balancing as Smoking Out}

Balancing is used to smoke out hidden unjustified ends in American constitutional law. The judicial decisionmaking process in any given case is a categorical one, in that it identifies prohibited governmental

constitutional issues generally regarded within the legal community as resolved by constitutional text itself").

132. See Fallon, supra note 77, at 1302-11. Fallon distinguishes among the following three understandings of strict scrutiny: "Strict Scrutiny as a Nearly Categorical Prohibition," "Strict Scrutiny as a Weighted Balancing Test," and "Strict Scrutiny as an Illicit Motive Test." Id. This Article correlates these three interpretations with the residual, true, and instrumental categories of balancing, respectively. See discussion infra Part III.C.3.a-c. 
purposes that are absolutely banned under the Constitution and deems them unconstitutional. There is no balancing entailed in the reasoning underlying this process. However, because prohibited purposes and motives of this kind can be camouflaged by the government as legitimate, and because it is difficult to find concrete evidence of prohibited purposes underlying governmental action, balancing becomes necessary. In many instances, what is referred to as balancing is often simply a means for smoking out illegitimate governmental objectives.

To this end, balancing can be used instrumentally in two ways. First, balancing to smoke out illegitimate purposes can be conducted through its means-ends tests. ${ }^{133}$ These tests look for instances in which the means do not match the ends. Assuming government rationality, such a lack of compatibility can be understood as indication that the stated ends are not the genuine ends. There are two principal means-ends tests: the existence of a close connection between the means and the end, and the least restrictive alternative test. Cass Sunstein's description of these two tests as they are applied in the context of heightened scrutiny expresses well how they are actually used to smoke out hidden illegitimate purposes:

\begin{abstract}
Heightened scrutiny involves two principal elements. The first is a requirement that the government show a close connection between the asserted justification and the means that the legislature has chosen to promote it. If a sufficiently close connection cannot be shown, there is a reason for skepticism that the asserted value in fact accounts for the legislation. The second element is a search for less restrictive alternatives - ways in which the government could have promoted the public value without harming the group or interest in question. The availability of such alternatives also suggests that the public value justification is a facade. ${ }^{134}$
\end{abstract}

An illustrative example of this smoking out is the Ho Ah Kow case, involving the so-called Queue Ordinance, enacted in 1873, that required the shaving of the heads of all inmates in San Francisco prisons. ${ }^{135}$ Prison hygiene - to prevent outbreaks of lice and fleas - was the alleged reason for this law, but in a lawsuit challenging the ordinance, the state court exposed this alleged justification as "mere pretense." Using means-ends analysis to smoke out the true, illicit motive, the court reasoned that if hygiene were the actual purpose, the ordinance would be both underinclusive - it included only men and convicts and

133. It is sometimes argued that means-ends tests are not balancing tests at all. However, for the purposes of this Article, it suffices to acknowledge that means-ends tests are widely viewed as balancing tests, and moreover, in European law, they lie at the heart of the proportionality test.

134. SUNSTEIN, supra note 121 , at 30.

135. Ho Ah Kow v. Nunan, 12 F. Cas. 252, 253 (C.C.D. Cal. 1879) (No. 6546).

136. Id. at 254 . 
not women or detainees - and overinclusive - heads could be checked for lice instead of the sweeping measure of shaving heads. ${ }^{137}$ The real objective, the court revealed, was to stop the influx of impoverished Chinese immigrants - who were desperate for food and shelter-into the prisons by requiring them to shave off an important symbol in their culture. ${ }^{138}$ Thus, in showing that the means were unsuited to the end, the court found that the ordinance was in fact driven by racism and unconstitutional motives.

Second, even if the means and ends are suited, courts can conduct a stricter sense of balancing by comparing the importance of the end-the urgency of the government need - with the amount of harm wrought on the right. Courts will strike down violations of rights when the harm is disproportionate either to the actual enhancement of the interest-when it is only marginal - or to the weight of the interest - when it is trivial. This balancing analysis can also be seen as a smoking out process. Because a rational actor would not ordinarily make such a poor tradeoff, it can be assumed that the government actor in such circumstances was motivated by goals other than those alleged. An argument in this spirit can be found in the hypothetical in which a teacher segregates black pupils from white pupils in the classroom for aesthetic reasons. ${ }^{139}$ Although a perfect fit between the means - the separation - and the goal - aesthetics - is possible, the fact that the aesthetic goal is so trivial raises suspicion that it is nothing more than an attempt at rationalizing the racist motive.

A concrete example of this type of smoking out can be found in Schneider, a well-known case from the 1930s in which the Supreme Court used balancing to deem unconstitutional a ban on the distribution of handbills in a city's streets. ${ }^{140}$ Here, the Court identified protection of free speech and street cleanliness as two considerations in its decision and argued that the latter is of such negligible weight that it is easily overridden by the former. ${ }^{141}$ That is, in the balance between free speech and cleanliness in that particular case, free speech outweighed cleanliness. However, the use of balancing in Schneider can be understood as

137. Id.

138. Id. at 255 .

139. Paul Brest, Processes of Constitutional Decisionmaking: Cases and MATERIALS 489 (1975); ElY, supra note 119, at 147-48.

140. Schneider v. State, 308 U.S. 147, 165 (1939).

141. Id. at 163 . 
bounded balancing because it was used to smoke out illegitimate purposes rather than actually balance between the two interests. ${ }^{142}$ The Court undoubtedly suspected that the laws in question were not really motivated by concern for cleanliness, but rather by concern with the messages on the handbills. This conclusion might have been based on the fact that the principal group distributing handbills was the Jehovah's Witnesses, whose views were disturbing to many people at the time. ${ }^{143}$ However, as the Court could not easily prove that prejudice is what underlay the ban, it used balancing as evidence of the existence of a message-related purpose, which is unconstitutional under First Amendment protections. ${ }^{144}$ The triviality of the cleanliness interest relative to the free speech interest was proof that the true motive behind the regulation was the desire to exclude disturbing and unpopular religious views. ${ }^{145}$

As previously demonstrated, such an application of balancing is compatible with the suspiciousness of American political culture. Rather than engaging in intrinsic balancing, courts use the instrumental bounded balancing to uncover cases of illegitimate governmental behavior.

\section{b. Balancing as the Exception Rather than the Rule}

Another way of understanding balancing as bounded in American constitutional law conceives of balancing as a kind of safety valve for exceptional occurrences in which rights protection would be extremely costly. Under this approach, balancing occurs even when it is not used to smoke out illegitimate purposes; its use is limited in this context, and it represents the exception in terms of rights interpretation rather than the rule. A prominent example of this type of balancing is the application of strict scrutiny review. Although strict scrutiny does allow for balancing, it functions much more like a rule that bans certain considerations altogether, such as considerations based on racial distinction. Balancing is allowed in extreme or exceptional cases in which the rule has to be set aside to avoid extreme outcomes. ${ }^{146}$ A second possible example is the "clear and present danger" test of American free speech jurisprudence

142. Cf. Rubenfeld, supra note 47 , at 831-32 (arguing that the ordinance in Schneider was targeted at speech).

143. Schneider, 308 U.S. at 158.

144. Id. at $163-65$.

145. Id.

146. See Fallon, supra note 77 , at 1303-06 (arguing that strict scrutiny often functions as a "[n]early [c]ategorical [p]rohibition" on certain types of infringements of rights, and that balancing enters the analysis only in extreme circumstances and as an exception to the categorical rule). 
from the early 1900s. ${ }^{147}$ This test allowed for the balancing of free speech against security or public safety concerns, but only when there was "clear and present danger" of public disorder. ${ }^{148}$ In effect, free speech was interpreted as setting a high bar for the regulation of opinions, and balancing was used only in the exceptional cases. ${ }^{149}$

The reason this type of balancing is termed "bounded" is because it is regarded as constrained by the rule rather than as describing the regular and standard template for rights analysis. Unlike what has been referred to as the intrinsic sense of balancing, where the entire conception of rights is based on the idea of balancing them with other considerations, the American bounded approach is that balancing, even if it does exist, represents the exception and not the rule.

\section{c. Balancing in the Strict Sense}

Admittedly, there are instances in American law in which "real" balancing occurs, that is, when the court is engaged in the comparison and accommodation of two competing interests or rights. This model of balancing comes closest to German proportionality: it is founded on the notion of the possibility of legitimate interests in conflict that require mutual consideration, as opposed to cases in which an illegitimate interest needs to be smoked out. However, in contrast to German proportionality, which is based on the ambitious goal of realizing the

147. Whitney v. California, 274 U.S. 357, 376 (1927); Gitlow v. New York, 268 U.S. 652, 671 (1925); Abrams v. United States, 250 U.S. 616, 627-28 (1919) (Holmes, J., dissenting); Schenck v. United States, 249 U.S. 47, 52 (1919).

148. Jonathan S. Masur, Probability Thresholds, 92 IowA L. REv. 1293, 1297 (2007) (noting that "[t]rue balancing - a full accounting on each side of the ledgersimply will not take place unless the probability of the asserted harm crosses the threshold").

149. In addition, see Rubenfeld, supra note 47, stating:

Despite appearances, the [clear and present danger test] cannot be understood as a balancing test. It should be understood rather as a test to determine whether an individual has intentionally used speech so closely and directly engaged with a particularized course of prohibited conduct that the individual may be treated as having participated in that conduct.

Id. at 829. Rubenfeld continued:

[The individual] can be punished for [participating in that conduct] — and not because the harmfulness of his speech outweighs its benefits. The same line of thought explains the unprotectedness of an entire set of speech acts "brigaded" with prohibited conduct: agreements to commit unlawful acts (conspiracy), Id. at 828

solicitations of unlawful acts, threats, and so on 
underlying values of the German constitution, American balancing, even in its strict sense, is usually based on a more pragmatic and minimalist approach. American balancing has historical ties to the pragmatic American movement of the early twentieth century and to figures such as Holmes, Pound, and Cardozo, who viewed law as a means to achieving social goals and balancing as the mechanism for implementing this approach. Thus, Holmes wrote in his Path of the Law that "judges . . . have failed adequately to recognize their duty of weighing considerations of social advantage." ${ }^{" 150}$ Cardozo invoked a balancing attitude when he wrote that legal decisions depend "largely upon the comparative importance or value of the social interest that will be thereby promoted or impaired." And Roscoe Pound wrote in favor of "a weighing of the social interest," arguing that "law is an attempt to satisfy, to reconcile, to harmonize, to adjust ... overlapping and often conflicting claims and demands." ${ }^{151}$ To this day, self-proclaimed pragmatists such as Posner, associate themselves with balancing. ${ }^{152}$

German proportionality, for its part, must be understood as emerging from German formalist jurisprudence. Originating in nineteenth-century German legal science, German legal formalism views law as an autonomous and logical science. ${ }^{153}$ Thus, despite its lofty and abstract goals, proportionality is the product of a legal frame of mind that is far more formalistic than the American one. In this context, the contemporary German legal scholar Bomhoff has provided a striking description of the differences between American balancing and German proportionality. Referring to the German Lüth decision, Bomhoff argues:

Lüth, in this view, becomes the embodiment of the European legal culture's will to believe that a formal, legal conception of the judicial weighing of interests or values is possible. Balancing, in this German or Continental view, does not have to be about policy choices, compromises or ad hocery, but can be about interpreting constitutional rights within a pyramidal, "objective" system of values. Balancing is not a discretion or an option; it can be a necessity, a constitutional obligation. Balancing may very well not "rigidify" in the way American adjudication has according to Schauer, because it already is highly

150. Oliver Wendell Holmes, The Path of the Law, in Collected Legal PaPers 167, 184 (1920) (emphasis added).

151. Roscoe Pound, A Survey of Social Interests, 57 HARV. L. REV. 1, 6, 39 (1943).

152. See, for example, Posner's criticism of the rejection of balancing in First Amendment jurisprudence, in Posner, supra note 47.

153. Indeed, a tension between radical formalism and an element of idealism and values has always existed in German jurisprudence and, in fact, typifies it. Such ambivalence can be found in nineteenth-century German jurisprudence. German legal science of that same period, or Rechtwissenschaft, made extensive use of exact science terminology to describe the scientific method by which the legal system operates; however, the legal scientist also sought to detect the moral, national, and historic core from which legal rules are derived. On this tension, see Reimann, supra note 87, at 88283. 
formal in other ways. And balancing does not need to be associated with ideology in the same way as Duncan Kennedy describes it for the U.S., because, put (perhaps too) bluntly: judicial balancing in constitutional cases does not have to be politics, it can be law. ${ }^{154}$

Thus, American balancing, even in its strict sense, can be understood as pragmatic and policy-oriented in contrast to the more abstract and conceptual German proportionality. And in this respect, American balancing, even in the strict sense, can be seen as bounded, albeit by pragmatic concerns and a pragmatic attitude.

\section{The Structural Constitutional Differences Between Germany and America}

The previous two sections showed how their respective political and legal cultures have assigned different meanings to German proportionality and American proportionality despite their analytical resemblance. This section will show how structural factors pertaining to constitutional architecture and the scope of constitutional rights are also responsible for the different extents to which the two doctrines are used in their respective legal systems. Indeed, in Germany, the expansive nature of constitutional rights creates a structural need for balancing in its intrinsic sense; in the United States, in contrast, the narrower scope of constitutional rights allows for the bounded type of balancing.

Rights are considerably broader in definition and scope in Germany than they are in America. This breadth is termed by German scholars as the "total application" of the constitution. ${ }^{155}$ This total application features three central characteristics. First, the wider scope of constitutional rights in Germany has resulted from the fact that its constitution speaks explicitly of underlying values and does not limit itself to the enumeration of rights; this has paved the way to an expansive constitutional approach to rights. ${ }^{156}$ Unlike rights, values are abstract entities in essence that can

154. Bomhoff, supra note 102 (footnotes omitted).

155. Mattias Kumm, Who's Afraid of the Total Constitution? Constitutional Rights as Principles and the Constitutionalization of Private Law, 7 GERMAN L.J. 341, 341-43 (2006), http://www.germanlawjournal.com/pdf/Vol07No04/PDF_Vol_07_No_04_341370 Articles\%20Kumm.pdf.

156. The German constitution opens with the words: "Human dignity shall be inviolable," and article 20(1) enunciates, "The Federal Republic of Germany is a democratic and social federal state." GRUNDGESETZ [GG] [Constitution] arts. 1(1), 20(1) (F.R.G.), available at http://www.bundestag.de/interakt/infomat/fremdsprachiges_material/ 
have very broad meaning. As a result, in Germany, almost any legitimate individual or collective interest is tied to a constitutional value and accorded constitutional status. ${ }^{157}$ The concept of rights in Germany is so broad that it has enabled the Constitutional Court to consider even such trivial interests as riding horses in the woods, feeding pigeons, smoking marijuana, and importing a certain breed of dog as constitutional rights. ${ }^{158}$ The American Constitution, in contrast, does not speak in terms of values but rather of enumerated rights. Furthermore, rights are often times interpreted more narrowly by delimiting their scope or excluding certain activities from that scope. A prominent example of this is the right to free speech, from which certain categories of speech have been excluded.

A second feature of this doctrine of total application is that, in contrast to the American constitutional conception of constitutional rights as solely negative rights, ${ }^{159}$ the German Constitutional Court has ruled that rights also have a protective, or positive, function. More specifically, the court has held that constitutional rights oblige the state to take any necessary measures in order to ensure their realization. ${ }^{160}$ For example, in 1972, it interpreted a constitutional provision guaranteeing that "all Germans shall have the right freely to choose ... their place of training",161 as imposing a duty on the state to provide schooling. ${ }^{162}$ In another case,

downloads/ggEn_download.pdf (English translation). See also article 19(2), which provides, "In no case may the essence of a basic right be affected." Id. art. 19(2).

157. Limits can be placed on any constitutional right in order to advance another constitutional value that is embedded in the constitution, either explicitly or implicitly, and that is ranked higher on the constitutional scale of values.

158. Kumm, supra note 4, at 141 .

159. DeShaney v. Winnebago County Dep't of Soc. Servs., 489 U.S. 189, 195-96 (1989); Jackson v. City of Joliet, 715 F.2d 1200, 1203 (7th Cir. 1983) (referring to the American Constitution as a "charter of negative rather than positive liberties"), cert. denied, 465 U.S. 1049 (1983); Bowers v. DeVito, 686 F.2d 616, 618 (7th Cir. 1982); cf. LAURENCE H. TRIBE, AMERICAN CONSTITUTIONAL LAW 998 (2d ed. 1988) (noting that in the context of free speech, the Court has suggested that the "government may, and perhaps must, act positively to reduce [private] repression [of the First Amendment]").

160. Dieter Grimm, The Protective Function of the State, in EUROPEAN AND US CONSTITUTIONALISM, supra note 21 , at 137, 137-38.

161. GRUNDGESETZ [GG] [Constitution] art. 12 (F.R.G.), available at http://www. bundestag.de/interakt/infomat/fremdsprachiges_material/downloads/ggEn_download.pdf (English translation).

162. Bundesverfassungsgericht [BVerfG] [Federal Constitutional Court] July 18, 1972, 33 Entscheidungen des Bundesverfassungsgerichts [BverfGE] 303 (F.R.G.), available at http://www.servat.unibe.ch/dfr/bv033303.html, stating:

The constitutional protection of basic rights in the field of education is not limited to the protective function against governmental intervention traditionally ascribed to the basic rights. Because the right would be worthless without the actual ability to make use of it, the entitlement of every German to carry out his chosen study program if he demonstrates the requisite qualifications . . . is not in the discretion of the lawmakers. 
the court interpreted the constitutional provision guaranteeing the right to life as placing an active duty on the state to enact criminal legislation banning abortion, and it further ruled that the state should also act to ensure that the mother's economic and occupational security are not impaired if she decides not to abort. ${ }^{163}$ In the United States, however, the Supreme Court decided that "although government may not place obstacles in the path of a woman's exercise of her freedom of choice to terminate her pregnancy, it need not remove those not of its own creation." 164 That is to say, the fact that women have the right to free choice and the state is therefore prohibited from banning abortions does not impose on the state a positive obligation to fund abortions.

Third, unlike the American reading of the Constitution, the German Constitutional Court has ruled that constitutional rights also apply indirectly in the context of relations between individuals; namely, the interpretation of the rules of private law should be in line with the values of the constitution-the Drittwirkung doctrine. ${ }^{165}$ The American Constitution, on the other hand, is not interpreted as granting rights protection to individuals in their relations with other individuals, but only to individuals vis-à-vis the state. ${ }^{166}$

Clearly, the broader the scope of constitutional rights, the more often they will clash. Therefore, the more expansive the conception of rights, the greater the need for a mechanism such as balancing for resolving conflicts among rights. Because everything counts in constitutional

Id. at 330 (author's translation). For example, the provision that secures a person's freedom to choose his or her specific vocation of study obliges the state to finance the studies. David P. Currie, Positive and Negative Constitutional Rights, 53 U. CHI. L. REV. 864, 871 (1986).

163. The second abortion case can be found in Bundesverfassungsgericht [BVerfG] [Federal Constitutional Court] May 28, 1993, 88 Entscheidungen des Bundesverfassungsgerichts [BVerfGE] 203 (F.R.G.), available at http://www.servat.unibe.ch/dfr/ bv088203.html, discussed in Kommers, supra note 86, at 870 .

164. Harris v. McRae, 448 U.S. 297, 316 (1980) (emphasis added).

165. Lüth, Bundesverfassungsgericht [BVerfG] [Federal Constitutional Court] Jan. 15, 1958, 7 Entscheidungen des Bundesverfassungsgerichts [BverfGE] 198 (F.R.G.) (author's translation), available at http://www.servat.unibe.ch/dfr/bv007198.html; see also Stephen Gardbaum, The "Horizontal Effect" of Constitutional Rights, 102 MicH. L. REV. 387, 415 (2003) (stressing the impact of constitutions on the rules of private law).

166. Lugar v. Edmondson Oil Co., 457 U.S. 922, 936 (1982). An exception to this rule can be found in Shelley v. Kraemer, 334 U.S. 1 (1948), in which the Court would not enforce a racist restrictive covenant, as court decisions constitute state actions. Id. at 4, 20. For criticism of Shelley, see Herbert Wechsler, Toward Neutral Principles of Constitutional Law, 73 HARV. L. REV. 1, 29-31 (1959). 
adjudication, rights are often conceived in Germany as an "optimization requirement." 167 In the United States, the narrower conception of rights makes conflict less pervasive. Moreover, constitutional rights are often perceived in America as shorthand for applying exclusionary reasons visà-vis the government, or limiting the scope of legitimate governmental ends. ${ }^{168}$ Whereas conflict is inherent in the German notion of rights as an optimization requirement and, hence, balancing is essential, the American concept of rights as exclusionary reasons makes conflict less likely because protecting rights means striking down illegitimate purposes rather than promoting legitimate ones. Balancing is therefore needed in the latter in its bounded sense of smoking out illegitimate purposes and not in the intrinsic sense.

\section{AFTERWORD: THE RAMIFICATIONS OF HELLER FOR THE FOREIGN LAW DEBATE}

This Article has attempted to show that, although there are no substantial analytical and doctrinal differences between American balancing and German proportionality, different meanings are assigned to each of these doctrines and they serve different functions in their respective legal systems. In Germany-which is the birthplace of proportionality and the most influential model of it-proportionality is a principal doctrine that encompasses such intrinsic values as moderation and compromise and that acts to integrate society under shared values. In addition, the expansive nature of rights under German constitutionalism creates a structural need for intrinsic balancing, making proportionality inevitable and central to the German model. In America, on the other

167. AleXY, supra note 104 , at $44,47-48,67,397$; HeSSE, supra note 98 , at 27 , $30-31$.

168. The term "exclusionary reasons" is taken from Josph Raz's practical reasoning philosophy. See Joseph Raz, Practical Reason AND NoRmS 35 (1999). It has been applied to describe American constitutional law. See Richard H. Pildes, Avoiding Balancing: The Role of Exclusionary Reasons in Constitutional Law, 45 HASTINGS L.J. 711, 711-12 (1994); see also Iddo Porat, On the Jehovah's Witnesses Cases, Balancing Tests, and Three Kinds of Multicultural Claims, 1 LAW \& ETHICS Hum. RTS. 429, 430, 440-41 (2007), http://www.bepress.com/lehr/vol1/iss1/art13/ (follow download link to access article); Iddo Porat, The Dual Model of Balancing, 27 CARdozo L. Rev. 1393, 1417-23 (2006). Some authors, while not making direct use of the term, have a similar conception of rights in American law. See, e.g., DworkIN, supra note 130, at 197-201, 234-36 (arguing rights are constructs designed to exclude those instances in which history has shown that the utilitarian tends to be corrupted by external preferences); Donald H. Regan, The Supreme Court and State Protectionism: Making Sense of the Dormant Commerce Clause, 84 Mich. L. REv. 1091, 1142 (1986) (interpreting the Commerce Clause as "excluding" protectionist motives); Rubenfeld, supra note 47, at $768,779-82,787,832$ (advocating a nonbalancing approach to free speech law in the United States). 
hand, balancing is more secondary and bounded by a more categorical approach towards rights. It is instrumental in smoking out illicit motives, it serves as proxy for a categorical approach, and when true balancing does take place, it is subsidiary and applied in a pragmatic fashion, quite different from the more idealistic and structured German model. Indeed, the narrower conception of rights in the United States gives rise to this subsidiary use of balancing, making it less central in American constitutional law.

In the context of the ongoing foreign law debate in the U.S. Supreme Court, it can be argued that Justice Breyer's move in Heller was not at all dramatic. If all that Justice Breyer did was label the specific type of balancing conducted in America with a foreign name, then he did not change the nature of that balancing. By using the term "proportionality" per se, he did not mandate the adoption of the German sense of intrinsic balancing. But this is true only to a certain extent: If the experience of other legal systems is any indication, the use of common terminology and common language may have drawn legal systems closer to one another. In that respect, Justice Breyer's tactic was not only backward looking - in showing similarities between American law and foreign law_-but it was also forward looking - creating a shared framework for dialogue and a mutual exchange of ideas between the United States and other democratic societies. Canada serves as a telling example of such a process.

In Canada, the introduction of proportionality into its constitutional law was accompanied by the introduction of continental organic conceptions of the state and an intrinsic type of balancing. While this does not establish a causal connection between proportionality and the migration of the German and continental constitutional model, it might nonetheless be an indication of the ability of proportionality to facilitate such a development by creating a common language, which allows for easier global migration. Indeed, although Canadian constitutional law has always diverged in many respects from the American system, ${ }^{169}$ it is

169. Although the American Declaration of Independence speaks of "life, liberty and the pursuit of happiness" principles that are commonly tied to Lockean libertarian ideas, the Canadian Constitution speaks of "peace, order and good government" principles that are tied to a more communitarian conception of the polity and that assume good faith on the part of the government rather than being wary of it. See RAND DYCK, CANADIAN POLITICS: CRITICAL APPROACHES (3d ed. 2000). Of note also is the following statement made by Alberta's former premier on the reasons why Canada should not adopt a constitutional bill of rights: "Canada has always operated under the 
a common law system and is more closely tied to the Anglo-American legal tradition than to the continental one. ${ }^{170}$ However, in several Supreme Court decisions over the last two decades, there is very clear evidence of a European type of reasoning and of what has been termed in this Article as intrinsic balancing; such analyses were not previously present in the Court's jurisprudence. ${ }^{171}$

This analytical evolution has been noted by commentators who argue that continental constitutional ideas - in particular, the language of underlying values and the broad conception of rights - have been imported into Canada. ${ }^{172}$ As previously mentioned, this coincided with the adoption of proportionality and its evolution into the central doctrine in Canadian Charter jurisprudence. ${ }^{173}$ Indeed, in 1986, four years after the adoption of the Canadian Charter, the Canadian Supreme Court recognized the European doctrine of proportionality by interpreting Section 1 of the Charter as including it. ${ }^{174}$ In the years to come, proportionality analysis

principles of responsible government and the sovereignty of the people as expressed through their legislators who are accountable to the people." Janet Hiebert, The Evolution of the Limitation Clause, 28 OsGOODE HALL L.J. 103, 110 (1990) (emphasis added). Some commentators speak specifically in terms of the symbiotic ties between the judiciary and the state in Canada. See Jamie Cameron, The Original Conception of Section 1 and Its Demise: A Comment on Irwin Toy Ltd. v. Attorney-General of Quebec, 35 McGill L.J. 253, 262 (1989); Ruth Colker, Section 1, Contextuality, and the AntiDisadvantage Principle, 42 U. TORONTO L.J. 77, 84-85, 100-05 (1992); Robin M. Elliot, The Supreme Court of Canada and Section 1: The Erosion of the Common Front, 12 QUEEN'S L.J. 277, 277-81 (1987); Frank Iacobucci, The Evolution of Constitutional Rights and Corresponding Duties: The Leon Ladner Lecture, U. B.C. L. REV. 1, 16-17 (1992).

170. For an account of the liberal Dworkinian ideas on the 1982 Canadian Charter of Rights and Freedoms, see PETER W. HogG, CONSTITUTIONAL LAW OF CANADA § 38.1-.3 (5th ed. 2007); see also DAVID BEATty, CONSTITUTIONAL LAW In THEORY AND PRACTICE 63, 108-09, 127 (1995); Lorraine Eisenstat Weinrib, The Supreme Court of Canada and Section One of the Charter, 10 SuP. CT. L. ReV. 469, 512 (1988).

171. See Reference re Secession of Que., [1998] 2 S.C.R. 217 (Can.); R. v. Butler, [1992] 1 S.C.R. 452 (Can.) (pornography); R.v. Keegstra, [1990] 3 S.C.R. 697 (Can.) (hate speech).

172. See sources cited infra notes 182, 186.

173. Proportionality law entered Canada in 1986. See R. v. Oakes, [1986] 1 S.C.R. 103 (Can.). The judgments with the "organic" style of reasoning are all from the 1990s. See cases cited supra note 171.

174. Section 1 of the Canadian Charter, which is often referred to as the "Limitation Clause," set the terms for the justifiable restriction of rights: "The Canadian Charter of Rights and Freedoms guarantees the rights and freedoms set out in it subject only to such reasonable limits prescribed by law as can be demonstrably justified in a free and democratic society." Part I of the Constitution Act, 1982, being Schedule B to the Canada Act 1982, ch. 11 (U.K.). This clause was interpreted in Oakes, 1 S.C.R. 103, to include the following proportionality test, which is very similar to the German test: First, the measures adopted must be carefully designed to achieve the objective in question. They must not be arbitrary, unfair or based on irrational considerations. In short, they must be rationally connected to the objective. Second, the means, even if rationally connected to the objective in this first 
became almost synonymous with constitutional analysis in Canada, becoming the most important doctrine in Canadian constitutional law. ${ }^{175}$ At the same time, several Canadian Supreme Court decisions using proportionality showed a clear continental influence. In the Keegstra case, ${ }^{176}$ for example, which dealt with hate speech, the courtfollowing what seems to be classic "organic" legal reasoning-ruled that the limitation clause has a dual function that links the guarantee of rights and freedoms to their limitations. ${ }^{177}$ Both rights and their limitations stem from the same set of values, which is embedded in the phrase "free and democratic society." 178 The role of the court is, hence, to weigh competing legitimate interests and to find the appropriate balance that best realizes these underlying values. In particular, the court considers which of the values are most closely connected to the paramount value of Canadian multiculturalism, similar to the human dignity prism in German constitutional law. The Canadian court stated that "Canada possesses a multicultural society in which the diversity and richness of various cultural groups is a value to be protected and enhanced"; furthermore, it held that "[m]ulticulturalism cannot be preserved let alone enhanced if free rein is given to the promotion of hatred against identifiable cultural groups." " It is is important to note that the dissenting opinion criticized the majority for watering down the distinction between rights and interests, arguing that the court was depicting a conflict "between philosophies" and "not between rights." "180

A second case that manifested even more clearly the migration of constitutional organic ideas is the Quebec Secession case, which dealt with the terms by which Quebec can secede from the Canadian

sense, should impair "as little as possible" the right or freedom in question.

Third, there must be a proportionality between the effects of the measures

which are responsible for limiting the Charter right or freedom, and the

objective which has been identified as of "sufficient importance." Id. at 139 (citation omitted).

175. See generally Sujit Choudhry, So What Is the Real Legacy of Oakes? Two Decades of Proportionality Analysis Under the Canadian Charter's Section 1, 34 SuP. CT. L. REV. 501, 505-21 (2006) (explaining the dominant role of proportionality analysis in Canadian constitutional law).

176. Keegstra, 3 S.C.R. at $735-36$.

177. Id.

178. Part I of the Constitution Act, 1982, being Schedule B to the Canada Act 1982, ch. 11 (U.K.).

179. Keegstra, 3 S.C.R. at 757,758

180. Id. at 833 (McLachlin, J., dissenting). 
Federation. ${ }^{181}$ In this decision, the court used particularly expansive language that echoed the underlying values rhetoric typical of the German and continental organic conception of the state. ${ }^{182}$ The constitution, declared the Canadian court, "is more than a written text. It embraces the entire global system of rules and principles which govern the exercise of constitutional authority." that " $[\mathrm{n}] \mathrm{o}$ single principle can be defined in isolation from the others, nor does any one principle trump or exclude the operation of any other." 184 Judicial reasoning is therefore not about exclusionary reasons; it is instead about moderation and compromise between competing and valid principles. In this case in particular, the outcome of the balancing analysis was tied to the values of moderation and compromise associated with intrinsic balancing. The court imposed a positive duty on both sides to negotiate in good faith the terms of secession. ${ }^{185}$ The case also served to promote dialogue in which the court and elected bodies bear joint constitutional responsibility. ${ }^{186}$

The Canadian example is a far cry from conclusive proof that the introduction of proportionality language into U.S. jurisprudence would result in a similar subsequent adoption of the European organic conception of the state. Compared to the United States, Canada may have been much more receptive to continental ideas from the outset. However, the Canadian case does seem to offer some evidence that proportionality facilitates the infiltration of continental constitutional ideas into a common law judicial system. At the very least, the appearance of proportionality seems to coincide with the adoption of a continental organic-based approach.

In conclusion, although this Article tried to show that American balancing is a distinct phenomenon from European proportionality in

181. See Reference re Secession of Que., [1998] 2 S.C.R. 217 (Can.) (presenting a full evaluation of the procedures for Quebec to secede from Canada).

182. Jean-François Gaudreault-Desbiens, Underlying Principles and the Migration of Reasoning Templates: A Trans-Systemic Reading of Quebec Secession Reference, in The Migration of Constitutional IDEAS, supra note 25, at 178, 189-207.

183. Reference re Secession of Que., 2 S.C.R. at 292.

184. Id. at 248

185. The Court ruled that "[n]o negotiations could be effective if their ultimate outcome, secession, is cast as an absolute legal entitlement based upon an obligation to give effect to that act of secession in the Constitution. Such a foregone conclusion would actually undermine the obligation to negotiate and render it hollow." Id. at 267.

186. See Sujit Choudhry \& Robert Howse, Constitutional Theory and the Quebec Secession Reference, 13 CAN. J.L. \& JURIS. 143, 160 (2000), who argue that the Canadian Court has in fact adopted a model of "joint constitutional responsibility." $I d$. Under this theory, in extraordinary cases in which the court lacks the institutional competency or legitimacy to translate abstract constitutional ideals into judicially enforceable standards, "it is for the political organs of the Constitution to frame their own interpretation of those norms and to assess their own compliance with them." Id. 
terms of meaning and function, this may change over time. The use of the term proportionality may help to open the door for European influences on American constitutional law. Arguably, such a move should have been done more openly by making the reference to foreign law explicit rather than implicit. 
